\title{
James Buchanan as Savior? Judicial Power, Political Fragmentation, and the Failed 1831 Repeal of Section 25
}

\begin{abstract}
A ntebellum Americans anticipated contemporary political science when they complained about the tendency of embattled political elites to take refuge in the judiciary. Recent scholarship on comparative judicial politics suggests that judicial review is a means by which constitutional framers provided protection for certain class interests that may no longer be fully protected in legislative settings. Tom Ginsburg claims, "[I]f they foresee themselves losing in postconstitutional elections," the politicians responsible for the constitution "may seek to entrench judicial review as a form of political insurance." Such a constitutional design ensures "[e]ven if they lose the election, they will be able to have some access to a forum in which to challenge the legislature."2 In 1801, Thomas Jefferson foreshadowed this strategy. He asserted that the defeated Federalist Party had "retired into the judiciary as a stronghold ... and from that battery all the works of republicanism are to be beaten down and erased."3 More than a half century later, Chief Justice David S.
\end{abstract}

* Professor of Law and Government, University of Maryland School of Law. This Article was written while the author was the 2008-09 Wayne Morse Chair at the University of Oregon School of Law. I am grateful to the Morse Foundation, Margaret Hallock, and Elizabeth Weber for their remarkable support. I am also grateful to numerous colleagues at the University of Maryland School of Law and elsewhere who read and commented on what follows without giggling too much.

1 TOM GINSBurg, Judicial Review in NEW Democracies: Constitutional COURTS IN ASIAN CASES 18 (2003).

2 Id.

${ }^{3}$ Letter from Thomas Jefferson to John Dickinson (Dec. 19, 1801), in 10 THE WRITINGS OF THOMAS JEFFERSON 301, 302 (Andrew A. Lipscomb ed., 1903); see also Letter from Thomas Jefferson to Joel Barlow (Mar. 14, 1801), in 10 THE WRITINGS OF 
Terry of the California Supreme Court repeated charges that judicial review in the United States provides politically unpopular factions with the institutional means for combating hostile electoral tides. ${ }^{4}$ His dissenting opinion in Ferris $v$. Coover insisted, "The decisions of the United States Supreme Court" authorizing federal review of state court decisions "embody the political principles of a party which has passed away." Recognizing "[t]he Legislative and Executive power of the Government had passed, or was rapidly passing into the hands of men entertaining opposite principles," Justice Terry continued, persons affiliated with the soon-to-be defunct Federalist Party sought "by a course of judicial decisions to give direction to the future policy of the Union." 6 Prominent public law scholars, writing almost 150 years later, christened this explanation of judicial empowerment as the "hegemonic preservation thesis"7 or "partisan entrenchment."8 " $[\mathrm{W}]$ hen their policy preferences have been, or are likely to be, increasingly challenged in majoritarian decision-making arenas," the leading contemporary champion of this perspective on judicial power asserts, "elites that possess disproportionate access to, and influence over, the legal arena may initiate a constitutional entrenchment of rights and judicial review in order to transfer power to supreme courts." Jefferson and Terry would certainly agree.

THOMAS JEFFERSON, supra, at 222, 223. Jefferson's chief lieutenant in the Senate, William Branch Giles, had informed his commander six months earlier that " $[t]$ he revolution [Republican success in 1800] is incomplete so long as that strong fortress [the Judiciary] is in possession of the enemy." 3 ALBERT J. BEVERIDGE, THE LIFE OF JOHN MARSHALL 22 (1919) (quoting Letter from William Branch Giles to Thomas Jefferson (June 1, 1802)) (second and third alterations in original); see also 1 CHARLES WARREN, THE SUPREME COURT IN UNITED STATES HISTORY 192-94 (rev. ed. 1926) [hereinafter 1 WARREN, THE SUPREME COURT]; Letter from James Monroe to Thomas Jefferson (Mar. 3, 1801), in 3 THE WRITINGS OF JAMES MONROE 261, 263-64 (Stanislaus Murray Hamilton ed., 1900).

4 Ferris v. Coover, 11 Cal. 175, 183 (1858) (Terry, C.J., dissenting).

5 Id.

6 Id. at 184.

7 RAN HIRSCHL, TOWARD JURISTOCRACY: THE ORIGINS AND CONSEQUENCES OF THE NEW CONSTITUTIONALISM 11 (2004). For the influence of Hirschl's "hegemonic preservation" thesis, see Ceren Belge, Friends of the Court: The Republican Alliance and Selective Activism of the Constitutional Court of Turkey, 40 LAW \& SOC'Y REV. 653, 657 (2006); Howard Gillman, How Political Parties Can Use the Courts to Advance Their Agendas: Federal Courts in the United States, 1875-1891, 96 AM. POL. SCI. REV. 511, 513 (2002).

8 Jack M. Balkin \& Sanford Levinson, Understanding the Constitutional Revolution, 87 VA. L. REV. 1045, 1066 (2001).

9 HIRSCHL, supra note 7, at 12. 
"Insurance," "hegemonic preservation," "partisan entrenchment," and related theses ${ }^{10}$ provide different explanations for the establishment and the expansion of judicial review than they give for the preservation of that constitutional power. United political coalitions empower courts. Diffuse political coalitions facilitate the maintenance of judicial authority. Political scientists document how political leaders of dominant national coalitions establish and expand the judiciary's authority to declare laws unconstitutional. When a united coalition controls the national government, judicial empowerment facilitates the implementation of the coalition's national policy in the hinterlands ${ }^{11}$ and is a long-term strategy for preserving power in the face of inevitable electoral weaknesses. ${ }^{12}$ The Republican Party majorities in Congress that expanded the jurisdiction of federal courts in 1875 and in 1891 sought to limit populist legislation in the states and entrench Republican constitutional visions in the House of Representatives against incoming Democratic majorities. ${ }^{13}$ Once created, scholars note, judicial power no longer needs active legislative assistance. Federal Justices retain the power to declare laws unconstitutional as long as either the once-dominant political elite or the new political sponsors for judicial authority retain sufficient control over national institutions to block hostile legislation aimed at courts. Justices are relatively free to declare laws unconstitutional during periods when control over electoral institutions is divided because electoral coalitions are typically unwilling or unable to challenge judicial pretensions. "[P]olitical diffusion is good for judicial power," Ginsburg notes. ${ }^{14}$ He and other scholars observe how "[p]olitical diffusion creates more disputes for courts to resolve and hinders authorities from overruling or counterattacking courts." 15 Sometimes fragmentation facilitates alliances between some elected officials and Justices. "Federalism,

10 "Regime Politics" is becoming the buzzword in political science. See generally J. Mitchell Pickerill \& Cornell W. Clayton, The Rehnquist Court and the Political Dynamics of Federalism, 2 PERSP. ON POL. 233 (2004).

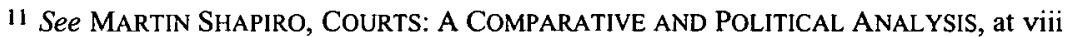
(1981) (describing courts as institutions "by which central political regimes consolidate their control over the countryside"); Jack N. Rakove, The Origins of Judicial Review: A Plea for New Contexts, 49 STAN. L. REv. 1031, 1042-50 (1997).

12 GINSBURG, supra note 1, at 18; see HIRSCHL, supra note 7, at 12; Balkin \& Levinson, supra note 8 , at $1067-68$.

13 Gillman, supra note 7, at 516-17.

14 GINSBURG, supra note 1 , at 261 .

$15 \mathrm{Id}$. 
separation of powers, and the particular structure of the American party system," Keith Whittington observes, "have played key roles in encouraging [P]residents to lend their support to the courts." other times, fragmentation inhibits efforts to change the course of judicial decisions. Roe v. Wade ${ }^{17}$ remained good law during the late twentieth century because pro-life forces were never able to establish the enduring control over both the Senate and the White House necessary to place a fifth Justice on the Supreme Court who was on record as being opposed to abortion rights. ${ }^{18}$

Constitutional authority, created by a unified political coalition, which subsequently feeds on political fragmentation, may be threatened by renewed unity in the elected branches of the national government. Judicial review, as hegemonic preservation, seems particularly vulnerable when the elites responsible for judicial empowerment fall so far from political grace that they lose the power necessary to prevent rival legislative coalitions from challenging the authority of judicial holdovers from the previous regime. Political transitions have proven too treacherous for activist judiciaries in many countries. During the late twentieth century, governing officials in Europe and Asia overrode judicial decrees, abolished courts, and arrested judges once judicial rulings trenched too severely on core concerns of their electoral coalitions. ${ }^{19}$

Analogous attacks on judicial power were unsuccessful in the United States, ${ }^{20}$ even during the youth and adolescence of the federal court system. Apparent realignments, "moments of intense, comprehensive, and periodically recurring systemic change in

\footnotetext{
16 Keith E. Whittington, Political Foundations of Judicial Supremacy: The PRESIDENCY, THE SUPREME COURT, AND CONSTITUTIONAL LEADERSHIP IN U.S. HISTORY 289 (2007).

17410 U.S. 113 (1973).

18 See Mark A. GRABER, RethINkING ABORTION: EQUAL CHOICE, THE CONSTITUTION, AND REPRODUCTIVE POLITICS 127 (1996).

19 Ran Hirschl, Beyond the American Experience: The Global Expansion of Judicial Review, in MARBURY VERSUS MADISON: DOCUMENTS AND COMMENTARY 129, 142-44 (Mark A. Graber \& Michael Perhac eds., 2002) [hereinafter MARBURY Versus MADISON].

20 The repeal of the Judiciary Act of 1801 may be an exception to the statement in the text, although that repeal merely restored the judicial status quo. The Judiciary Act of 1862 may be a better example of a successful attack on the judiciary. That measure adjusted the federal circuit court system, guaranteeing a Northern majority on the Supreme Court for the foreseeable future. While not abolishing judicial power, the restructuring of the federal court system altered the beneficiaries of that practice.
} 
American politics," the politics of the past," 22 did little to diminish the judicial power to declare laws unconstitutional. Political coalitions that included leading critics of judicial power failed to curb courts after taking power. Jeffersonians did not successfully impeach Justice Samuel Chase in $1803,{ }^{23}$ and, in 1831 , Jacksonians lacked the votes to abolish the most important statutory foundation for federal judicial authority. President Roosevelt discovered that his landslide electoral victory in 1936 did not provide adequate political foundations for challenging recalcitrant federal courts in $1937 .^{24}$

James Buchanan is often credited with being the unlikely savior of judicial review in early Jacksonian America. In 1831, the House Judiciary Committee issued a report calling on Congress to repeal section 25 of the Judiciary Act of $1789 .^{25}$ That provision authorized the Supreme Court to review state court decisions upholding state laws against federal constitutional attack, declaring federal laws unconstitutional, or rejecting claims of federal constitutional right. ${ }^{26}$ Repeal, for all practical purposes, would have abolished federal judicial review of state laws and severely curtailed federal judicial review of national laws. ${ }^{27}$ Buchanan, then a congressional representative from Pennsylvania, issued a minority report, on behalf of himself and the two other dissenting members of the House

2I Walter Dean Burnham, Critical Realignment: Dead or Alive?, in THE END OF REALIGNMENT?: INTERPRETING AMERICAN ELECTORAL ERAS 101, 115 (Byron E. Shafer ed., 1991) [hereinafter Burnham, Critical Realignment].

22 STEPHEN SKOWRONEK, THE POLITICS PRESIDENTS MAKE; LEADERSHIP FROM JOHN ADAMS TO GEORGE BUSH 33 (1993).

23 The best study of the Chase impeachment is Keith E. Whittington, Reconstructing the Federal Judiciary: The Chase Impeachment and the Constitution, 9 STUD. AM. POL. DEV. 55 (1995).

24 The classic study of the "Court-packing" plan is WILLIAM E. LEUCHTENBURG, THE Supreme COURT REBORN: THE CONSTITUTIONAL REVOlution IN THE AgE OF ROOSEVELT 82-162 (1995).

25 Report Upon the Judiciary, 7 REG. DEB. app. at lxxvii (1831).

26 Judiciary Act of 1789 , ch. 20, § 25, 1 Stat. 73, 85-86 (1789).

27 Many antebellum lawsuits challenging federal laws were initiated in state courts. To the extent state court decisions could not be appealed to the Supreme Court, federal courts would lose control over the authority to determine whether federal laws were constitutional. See infra notes 95-98. In fact, section 25 limited federal court control by permitting appeal only when the state court declared a federal law unconstitutional. $\S 25$, 1 Stat. at 85-86; see also Maeva Marcus \& Natalie Wexler, The Judiciary Act of 1789: Political Compromise or Constitutional Interpretation?, in ORIGINS OF THE FEDERAL JUDICIARY: ESSAYS ON THE JUDICIARY ACT OF 1789, at 13 (Maeva Marcus ed., 1992). 
Judiciary Committee, criticizing the proposed repeal of section $25^{28}$ His analysis is generally credited with convincing a skeptical Congress that fundamental constitutional norms required federal judicial oversight of state courts and state legislatures. "[I]t was largely due to [Buchanan's] efforts," Charles Warren writes, "that the [repeal] bill was finally defeated." 29 Felix Frankfurter and James Landis regard Buchanan's defense of federal judicial authority as "one of the famous documents of American constitutional law."30

Why judicial review survived the Jacksonian Revolution and what motivated Jacksonian politicians such as Buchanan to support federal judicial authority remains remarkably under-theorized. The most important study on the politics of federal jurisdiction before the Civil War, Charles Warren's magisterial "Legislative and Judicial Attacks on the Supreme Court of the United States-A History of the TwentyFifth Section of the Judiciary Act," was published in 1913. That essay devoted only a paragraph to the effort to repeal section 25 in 1831. W1 Warren cited numerous instances when "Old Republicans" and radical Jacksonians proposed court-curbing measures but made little effort to explain why those attempts failed to curtail federal judicial power. He concluded with the bald assertion: "[T]here has been entire acquiescence by the States and by. the people in the jurisdiction granted to the Supreme Court by the United States Constitution."32 . No explanation was given for this acquiescence. The literature on realignment is no more instructive on the survival of judicial review in Jacksonian America. Walter Dean Burnham claims that "the outbreak of political conflict over the Supreme Court's role and decisions" is an important manifestation of an impending political

\footnotetext{
28 Counter Report Upon the Judiciary, 7 REG. DEB. app. at Ixxxi (1831).

29 Charles Warren, Legislative and Judicial Attacks on the Supreme Court of the United States-A History of the Twenty-Fifth Section of the Judiciary Act (pt. 2), 47 AM. L. REV. 161, 164 (1913) [hereinafter Warren, Legislative and Judicial Attacks (pt. 2)]; see also Wilfred Feinberg, Constraining "The Least Dangerous Branch": The Tradition of Attacks on Judicial Power, 59 N.Y.U. L. REV. 252, 259 (1984); Robert J. Pushaw, Jr., Congressional Power Over Federal Court Jurisdiction: A Defense of the Neo-Federalist Interpretation of Article III, 1997 BYU L. REV. 847, 882 n.149 (1997) ("Buchanan's dissent was so persuasive that the full House overwhelmingly rejected the bill.").

30 FELIX FrankFURTER \& JAMES M. LANDIS, THE BuSINESS OF THE SUPREME COURT: A STUDY IN THE FEDERAL JUDICIAL SYSTEM 44 n. 143 (1928); see also 1 WARREN, THE SUPREME COURT, supra note 3, at 739; Akhil Reed Amar, Taking Article III Seriously: A Reply to Professor Friedman, 85 Nw. U. L. REV. 442, 450 (1991).

31 Warren, Legislative and Judicial Attacks (pt. 2), supra note 29, at 164.

32 Id. at 189.
} 
transition. ${ }^{33}$ He refers to Jacksonian efforts to "curb the Court" as evidence that a realignment took place in "the period 1827-35.,34 Burnham does not explain why such an important marker of the political disruptions of the early Jacksonian period - court-curbingnevertheless failed.

This Article claims that federalism and political fragmentation were more responsible than James Buchanan for the failed repeal of section 25, for the maintenance of judicial power in the United States during the transition from National Republican rule to Jacksonian democracy that took place during the $1820 \mathrm{~s}$ and 1830 s, and for the maintenance of judicial power in the United States during other political transitions. The congressional vote on the House Judiciary Report proposing the repeal and contemporaneous newspaper responses to that proposal indicate that, outside of political actors residing in the handful of states with immediate reasons for curtailing the jurisdiction of federal courts, most Americans supported the Supreme Court's power to declare federal and state laws unconstitutional. The Marshall Court enjoyed popular support during the 1820s because that tribunal's most important decisions targeted state laws that were inconsistent with policies favored by national elites. ${ }^{35}$ Americans did not repudiate the Marshall Court's constitutional vision by electing Andrew Jackson in 1828. Jackson rode to power on the back of a geographically diverse coalition composed of members who sharply disputed the constitutionality of the national bank, protective tariffs, and other matters that had been adjudicated, or were likely to be adjudicated, by federal courts in the near future. Members of a badly fragmented political coalition, radical Jacksonians could not even gain a majority of Jacksonian votes for curbing judicial power in 1831. When Jacksonians reached a consensus that the national bank and protective tariffs were unconstitutional during the late $1830 \mathrm{~s}$, no pressing need existed to limit the power of a Supreme Court that, by then, was staffed by a Jacksonian majority committed to the Jacksonian constitutional vision.

The Jacksonian experience highlights how political diffusion helps preserve judicial power both during periods of political stability,

\footnotetext{
33 Burnham, Critical Realignment, supra note 21, at 124.

34 Id.

35 See McCulloch v. Maryland, 17 U.S. (4 Wheat.) 316 (1819); Fletcher v. Peck, 10 U.S. (6 Cranch) 87 (1810); see also infra notes 153-57 and accompanying text.
} 
when no existing coalition fully controls the national government, and during periods of political reconstruction or realignment, when a new coalition gains control of the national government. Political scientists have detailed that elected officials have a tendency to foist responsibility for constitutional decisions on courts during times when there is no constitutional consensus in the elected branches of a national government. Persons opposed to the direction of judicial decisions at those times lack the power to reverse the courts. ${ }^{36}$ As events from 1828 to 1837 demonstrate, political diffusion is also "good for judicial power" during the political transitions that take place while a new dominant coalition is consolidating power. The more power is diffused, the greater the challenges of putting together a partisan coalition that shares a coherent constitutional vision. The greater the difficulty of unifying a dominant national coalition, the longer the time necessary to gain the control over the elected branches of the national government necessary to curb contrary judicial pretensions. Basically, when a new ruling coalition first comes to power, the party is likely to lack the necessary unity or control over national institutions to attack a judiciary still committed to inherited constitutional visions. By the time the coalition becomes sufficiently united and powerful, the combination of deaths, resignations, and new judicial appointments is likely to make attacks on judicial power unnecessary. Put more simply, the more power is diffused, the less likely that, at some point in a political transition, the emerging coalition will have adequate control of all electoral institutions during the time it has inadequate control of the courts.

Once a new, cohesive national coalition gains the control over the federal government necessary to alter judicial power, expansion and hegemonic preservation are likely to be better political strategies for realizing their constitutional vision than court-curbing proposals. The surviving Justices who most need curbing after a political coalition has consolidated are likely to be speaking only when dissenting from opinions penned by Justices who share the new regime's constitutional commitments. More often than not, during the later stages of a political transition, the judiciary is likely to be a vital presidential ally against a recalcitrant Congress. Presidents typically play the crucial role in political reconstructions. "Disruption of the status quo ante," Stephen Skowronek explains, "is basic to the politics

36 See Mark A. Graber, The Nonmajoritarian Difficulty: Legislative Deference to the Judiciary, 7 Stud. A.M. POL. Dev. 35, 59-60 (1993). See generally WhiTTINGTON, supra note 16 , at $82-229$. 
presidents make."37 Presidents also typically have more influence than legislators on the staffing of federal courts. Presidents tend to nominate Justices whom they believe share their constitutional vision. $^{38}$ Senators tend to confirm the President's nominees whom they believe are competent and not ideological extremists. ${ }^{39}$ As a result, the Supreme Court is likely to be politically closer to the President than the median member of the House of Representatives or the Senate. ${ }^{40}$ By 1840 , the Taney Court was more reliably Jacksonian than the Congress. When Roosevelt left office, the Supreme Court was far more committed to the constitutional vision underlying the New Deal than either the House or the Senate. Given the special presidential role in political reconstructions and in reconstructing the federal courts, a high probability exists that the federal judiciary will become committed to the President's constitutional agenda before, or at approximately the same time as, the Congress. When the new dominant coalition finally captures control of the national legislature, therefore, its constitutional commitments will best be promoted by legislation expanding the authority of an already friendly judiciary.

My claim that new political coalitions are likely to have immediate reasons for expanding judicial power, once they both reach a consensus on constitutional goals and control all elected branches of government, differs from William Lasser's more strategic explanation for the survival of judicial review during periods of political transitions. ${ }^{41}$ Lasser asserts that the leaders of emerging popular majorities have sometimes behaved tactically, preferring to tolerate judicial challenges to cherished policies in the present for the prospect of a powerful judiciary stacked with their partisans in the future. ${ }^{42}$ Because reconstructive Presidents, such as Abraham Lincoln and Franklin Roosevelt, "remained essentially friendly to the idea of a strong federal judiciary exercising power on behalf of a powerful

37 SKOWRONEK, supra note 22, at 4.

38 See Henry J. Abraham, Justices, Presidents, ANd SENATORS: A History of THE U.S. SUPREME COURT APPOINTMENTS FROM WASHINGTON TO BUSH II, at 52-56 (5th ed. 2008); LEE EPSTEIN \& JEFFREY A. SEGAL, ADVICE AND CONSENT: THE POLITICS OF JUDICIAL APPOINTMENTS 130-35 (2005).

39 Charles M. Cameron, Albert D. Cover \& Jeffrey A. Segal, Senate Voting on Supreme Court Nominees: A Neoinstitutional Model, 84 AM. POL. SCI. REV. 525, 530-31 (1990).

40 See Mark A. Graber, Does It Really Matter? Conservative Courts in a Conservative Era, 75 FORDHAM L. REV. 675, 691 (2006).

41 WiLliam Lasser, THE Limits of Judicial POWER: THE SUPREME COURT IN AMERICAN POLITICS 258 (1988).

42 See id. at $258-59$. 
national government ... [and expected] the Court [to] become their ally in the long run," he states, "they set out not to destroy the Court but only to capture it."

James Buchanan did not make such an appeal to the future in 1831 when he sought to maintain section 25. Buchanan urged Jacksonians and National Republicans to preserve the power of a judiciary committed, at the time, to the constitutionality of the national bank and protective tariffs because, for the time being, he and a majority of the representatives in Congress favored these initiatives. By the time Buchanan and other northern Democrats abandoned their commitment to the national bank and protective tariffs, so too had the Supreme Court.

The following pages explore how judicial review survived the transition from the deferential politics of the National Republican/Federalist era to the partisan politics of Jacksonian America. Part I details the political foundations of federal judicial power, particularly the crucial role section 25 of the Judiciary Act of 1789 played in establishing and maintaining the Supreme Court's power to declare state-and federal-laws unconstitutional. Part II explains why the transition from Federalist to National Republican rule during the beginning of the nineteenth century posed little threat to judicial authority. Part III discusses the Jacksonian challenge to federal judicial power, why that challenge failed in 1831, and why that challenge was largely abandoned by 1837 . Part IV points out how political fragmentation explains the failure of both the Jacksonian challenge to judicial power and the subsequent attacks on the judiciary in American history. This analysis concludes that judicial review is likely to become a permanent feature of the constitutional landscape once established in a polity where power is almost always fragmented.

Perceptions of judicial weakness during crucial junctures of American history are rooted in realignment theory, ${ }^{44}$ which is currently being discarded by students of American political development. $^{45}$ Realignment theorists contended that American politics was structured by sharp alterations in partisan control of

43 Id. at 258.

44 The seminal statement of realignment theory is Burnham, Critical Realignment, supra note 21, at 101-03. For a good summary of the literature on realignment, see David R. Mayhew, Electoral Realignments: A CRITIQUe of an AMERICAN GenRe $1-33(2002)$.

45 The most important criticism is found in MAYHEW, supra note 44, at 34-140. 
national institutions that tended to take place on a cycle of approximately thirty years. One or two national elections were sufficient to replace one majority with a new majority committed to a very different constitutional vision. Federal courts were presumed to be particularly less vulnerable during these rapid transitions, as the judiciary was the only national institution whose members were immune from the immediate effects of the electoral tide. ${ }^{46}$ A united coalition in the elected branches of government, conventional wisdom indicated, could not achieve goals unless adherents of the old order in the judiciary could be immediately replaced or induced to change course. "In the course of establishing their own constitutional vision," Whittington asserts, reconstructive "[P]residents must necessarily shatter previously established constitutional understandings laid down by the Court." 47

This realignment synthesis no longer seems to describe American politics. Political scientists at the dawn of the twenty-first century now depict numerous, partly autonomous government institutions, each of which has a partly autonomous developmental trajectory. ${ }^{48}$ The buzzword to describe this phenomenon is "intercurrence." political universe characterized by intercurrence, sharp shifts do not simultaneously occur in all elected institutions. At most, the House of Representatives, the Senate, the President, and the federal courts may be moving in similar, although not identical, ideological directions at very different speeds. By the time all the electoral "ducks are in line," if that ever occurs, the same phenomenon is likely to move the Supreme Court to a place where at least some crucial members of the dominant national coalition are more inclined to see the Justices as their allies against members of their coalition who have somewhat different beliefs.

The evidence from 1831 and other years suggests that judicial power thrives in a political environment characterized more by intercurrence than realignment. In political environments characterized by intercurrence, the political institutions that must unite for a successful challenge to federal courts are rarely on the same page. Challenges to judicial authority occur more frequently

\footnotetext{
46 See WhiTTINGTON, supra note 16 , at 28-81.

47 Id. at 77.

48 See Karen ORRen \& STEPHEN SKOWRONEK, THE SEARCH FOR AMERICAN POLITICAL DEVELOPMENT 108-18 (2004).

${ }^{49} \mathrm{Id}$. at 108.
} 
because, in a world of relatively autonomous elected branches of national government, at least one branch is likely to be seriously at odds with decision-making trends on the Supreme Court. These more frequent challenges are also likely to fail because other elected branches of the national government are more likely to be moving in step with the judicial majority than the challenging branch. Southern Jacksonians learned, to their sorrow, that the political transformations that gave them the power to elect one of their own as Speaker of the House were not sufficient to align the rest of the Congress against the Supreme Court in 1831.

\section{THE FOUNDATIONS OF JUDICIAL AUTHORITY}

\section{A. Some Basics}

Judicial authority has political foundations. ${ }^{50}$ Justices only have the power to declare laws unconstitutional, in a politically significant sense, ${ }^{51}$ when the following occur: a judicial system is established, that judicial system is staffed, the courts are vested with jurisdiction over cases raising constitutional questions, litigants actually raise claims challenging the constitutionality of official actions, judges possess the resources necessary to resolve constitutional disputes in a timely and intelligent manner, outsiders do not exercise undue influence over judges considering constitutional issues, and judicial decisions declaring laws unconstitutional are obeyed. ${ }^{52}$ These prerequisites for judicial review require legislation and executive power. ${ }^{53}$ Justices do not create judicial systems. ${ }^{54}$ Federal judicial review did not exist in the Confederacy because, although the Confederate Constitution called for the establishment of a Supreme Court, "the prevailing political determination [was] to leave the Supreme Court [of the Confederate States of America]

50 See Mark A. Graber, The Law and Politics of Judicial Review, in SEPARATION OF POWERS: DOCUMENTS AND COMMENTARY 49, 54 (Katy J. Harriger ed., 2003). See generally WHITTINGTON, supra note 16.

51 Most persons above the age of three can utter the declaratory statement: "This law is unconstitutional."

52 Mark A. Graber, Establishing Judicial Review: Marbury and the Judiciary Act of 1789, 38 TULSA L. REV. 609, 618-22 (2003).

53 See id. at 618.

54 Id. 
unorganized." ${ }^{55}$ Action by elected officials is often necessary to ensure that judicial authority is not compromised by outside threats to judicial personnel or litigants. State failure to redress private violence during the Jim Crow era prevented numerous persons of color from litigating constitutional claims in the Deep South. ${ }^{56}$

The political foundations of judicial authority suggest political explanations for the power to declare laws unconstitutional. Rather than parse only legal texts for the origins of judicial review, scholars should also determine why elected officials empowered courts to ignore or strike down legislative acts. "For constitutions and institutions like judicial review to exist in historical reality and be more than imagined moral abstractions," Keith Whittington observes, "there must be political reasons for powerful political actors to support them over time." ${ }^{, 57}$ That Justices exercise the power to declare laws unconstitutional when given legal and political opportunities, while not unproblematic, is not surprising. Determining what motivates national legislators and chief executive officials to provide Justices with those legal and political opportunities is more difficult. Legislative majorities seemingly have strong incentives to limit judicial authority if, as Alexander Bickel famously maintained, "when the Supreme Court declares unconstitutional a legislative act or the action of an elected executive, it thwarts the will of representatives of the actual people of the here and now." 58

Contemporary scholarship has documented numerous legislative motivations for empowering federal courts. Judicial review in practice is not nearly as countermajoritarian as Bickel suggested. Courts serve the interests of at least some members of the dominant national coalition when Justices strike down state laws that are inconsistent with national constitutional visions, declare politics enacted by a previous regime unconstitutional, and resolve political controversies that cut across existing political coalitions. ${ }^{59}$ Elected

\footnotetext{
55 Marshall L. DeRosa, THE CONFEDERATE CONSTITUTION OF 1861: AN INQUIRY INTO AMERICAN CONSTITUTIONALISM 104 (1991).

56 See Gerald N. Rosenberg, The Hollow hope: Can Courts Bring about Social Change? 82-83 (2d ed. 2008).

57 See WHITTINGTON, supra note 16 , at 4.

58 ALEXANDER M. Bickel, THE LEAST Dangerous BRANCH: THE Supreme COURT AT THE BAR OF POLITICS 16-17 (1962).

59 Scholarship on the political construction of judicial power has become a major growth industry in political science. See, e.g., HIRSCHL, supra note 7, at 11-12; GEORGE I. LOVEll, LeGiSlative DEFERRALS: STATUTORY AMBiguity, JUdiCIAL POWER, AND
} 
officials probably have less self-interested motives when expanding or preserving judicial power. Broad agreement exists in the United States both that Marbury v. Madison was correctly decided and that judicial review is a necessary component of constitutional government. ${ }^{60}$ At the very least, such beliefs likely create a political presumption in favor of judicial authority, which inhibits courtcurbing actions, unless the provocation is particularly strong.

These political foundations and explanations highlight the importance of the various judiciary laws that national officials have debated and enacted throughout American history. These measures play at least as important a role as judicial opinions in establishing, maintaining, and expanding judicial power. Measures such as the Judiciary Act of $1789,{ }^{61}$ the Judiciary Act of $1837,{ }^{62}$ the Judiciary Act of $1875,{ }^{63}$ the Judiciary Act of $1891,{ }^{64}$ and the Judiciary Act of $1925^{65}$ created the federal court system, provided for the appointment of Justices, and vested federal courts with jurisdiction over constitutional cases. The debates over whether to pass and maintain these Acts are probably the most important source for determining why elected officials empower courts. As Charles Fairman astutely noted, "The historian of the Court should keep his watch in the halls of Congress." 66 Fairman's advice, forgotten by most of the grand constitutional theorists of the late twentieth century, was gospel before the Civil War.

AMERICAN DEMOCRACY 1-41 (2003); KEVIN J. MCMAHON, RECONSIDERING RoOsevelt on RaCE: How the PRESIDENCY PAVEd THE RoAd TO BROWN 6-20, 144 50, 205-21 (2004); WhitTington, supra note 16, at 1-27; Paul Frymer, Acting When Elected Officials Won't: Federal Courts and Civil Rights Enforcement in U.S. Labor Unions, 1935-85, 97 AM. POL. SCI. REV. 483, 484 (2003); Gillman, supra note 7, at 511; Graber, supra note 36, at 65-68. For one summary of this literature, see Mark A. Graber, Constructing Judicial Review, 8 ANN. REV. POL. SCI. 425 (2005).

60 See, e.g., ROBERT H. BORK, THE TEMPTING OF AMERICA: THE POLITICAL SEDUCTION OF THE LAW 24-25 (1990); RONALD DWORKIN, FREEDOM'S LAW: THE MORAL READING OF THE AMERICAN CONSTITUTION 33-34 (1996).

61 Judiciary Act of 1789, ch. 20, I Stat. 73 (1789).

62 Judiciary Act of 1837, ch. 34, 5 Stat. 176 (1837).

63 Judiciary Act of 1875, ch. 137, 18 Stat. 470 (1875).

64 Judiciary Act of 1891, ch. 517, 26 Stat. 826 (1891).

65 Judiciary Act of 1925, ch. 229, 43 Stat. 936 (1925).

66 CHARLES FAIRMAN, 6 History OF THE SUPREME COURT, RECONSTRUCTION AND REUNION, 1864-88, pt. 1, at 118 (1971). 


\section{B. Political Foundations in the United States}

The basic foundations for the judicial power to declare laws unconstitutional in the United States were initially established by the ratifiers of the Constitution of the United States. Article III, Section 2 asserts, "The judicial Power shall extend to all Cases, in Law and Equity, arising under this Constitution., ${ }^{, 67}$ While not stating so explicitly, this provision could plausibly be interpreted as authorizing federal courts to declare laws unconstitutional. ${ }^{68}$ The Supremacy Clause, which asserts that "[t]his Constitution ... shall be the supreme Law of the Land," provides a second textual foundation for judicial review. ${ }^{69}$ This seems to have been the original expectation of most framers who discussed judicial review during the framing and ratification process. $^{70}$

The First Congress provided more explicit foundations for judicial power by passing the Judiciary Act of 1789 . In sharp contrast to the Constitution, that measure plainly empowers the Supreme Court to declare state and federal laws unconstitutional. Any state court decision that either holds that a federal law or treaty is unconstitutional, determines that a state law is constitutional, or rejects a claim of federal constitutional or statutory right "may be reexamined and reversed or affirmed in the Supreme Court of the United States." ${ }^{\text {71 }}$ Other provisions of the Judiciary Act provide necessary prerequisites for judicial power. In 1789, Congress determined the number of federal Justices, required federal courts to hold regular sessions for hearing and deciding cases, provided the court with personnel and processes that both assisted judicial decision making and facilitated the implementation of judicial decisions, created federal officers who could litigate constitutional issues before the Supreme Court, and authorized salaries for various judicial officers. $^{72}$ The congressional decision to vest state courts with original jurisdiction over most claims based on federal constitutional law may have furthered federal judicial power by making

\footnotetext{
67 U.S. CONST. art. III, § 2.

68 See Marbury v. Madison, 5 U.S. (1 Cranch) 137, 178-79 (1803).

69 See Herbert Wechsler, Toward Neutral Principles of Constitutional Law, 73 HARV. L. REV. 1, 3-4 (1959).

70 See MARBURY VERSUS MADISON, supra note 19, at 235-37.

71 Judiciary Act of 1789, ch. 20, $\$ 25,1$ Stat. 73, 85-86 (1789).

72 Id. $\S \S 1-35,1$ Stat. at 73-93.
} 
constitutional litigation more convenient and less expensive. ${ }^{73} \mathrm{Had}$ the Judiciary Act of 1789 or a similar proposal failed to become federal law, subsequent debates over judicial review and judicial supremacy would have been purely speculative.

Marbury v. Madison and related cases that asserted a judicial power to declare laws unconstitutional did little more than announce a judicial willingness to exercise the power granted by Congress in $1789 .^{74}$ In 1803 , the Justices made no short-term contribution to the political authority of federal courts. At best, the Marshall Court may have preserved a preexisting judicial power by not handing down a decision that might have provoked hostile officials in the Jefferson administration. $^{75}$ Marshall's opinion did not even make an original contribution to the intellectual case for judicial review. The Marbury opinion largely repeats the main arguments of The Federalist Number $78,{ }^{76}$ Justice William Paterson's opinion in Vanhorne's Lessee $v$. Dorrance, ${ }^{77}$ and, most substantively, claims leading Federalists made during the debate over the Repeal Act of $1802 .^{78}$

To the extent that Marbury provided legal foundations for a judicial power beyond that found in the Judiciary Act of 1789 , Marshall did so by asserting that Justices could declare official actions unconstitutional whenever they had jurisdiction over a caseor when deciding whether jurisdiction had been constitutionally

73 See Akhil Reed Amar, Marbury, Section 13, and the Original Jurisdiction of the Supreme Court, 56 U. CHI. L. REV. 443, 455-56 (1989); James E. Pfander, Marbury, Original Jurisdiction, and the Supreme Court's Supervisory Powers, 101 COLUM. L. REV. 1515,1519 (2001).

${ }^{74}$ Marbury was not the first federal court decision that indicated federal courts had the power to declare laws unconstitutional. See United States v. Ferreira, 54 U.S. (13 How.) 40, 53 (1851) (discussing United States v. Yale Todd (U.S. 1794)); Hollingsworth v. Virginia, 3 U.S. (3 Dall.) 378 (1798); Vanhorne's Lessee v. Dorrance, 2 U.S. (2 Dall.) 304 (1795); Hayburn's Case, 2 U.S. (2 Dall.) 409 (1792); United States v. Callender, 25 F. Cas. 239, 256 (C.C.D. Va. 1800) (No. 14,709). See generally Scott Douglas Gerber, The Myth of Marbury v. Madison and the Origins of Judicial Review, in MARBURY VERSUS MADISON, supra note 19, at 11-13; Graber, supra note 52, at 626-27.

75 See Robert G. MCCloskey, The AMERICAN SuPreme Court 25-27 (Sanford Levinson ed., 3d ed. 2000); Mark A. Graber, The Problematic Establishment of Judicial Review, in THE SuPREME COURT IN AMERICAN Politics: New InstituTionalist INTERPRETATIONS 28, 36 (Howard Gillman \& Comell Clayton eds., 1999).

76 ThE FEdERALIST No. 78 (Alexander Hamilton) (Jacob E. Cooke ed., 1961).

772 U.S (2 Dall.) 304, 309-15 (1795).

78 See, e.g., 11 ANNALS OF CONG. 25-30, 32-34, 38, 39, 48, 50, 56-59, 61-63, 73-75, $83,89,91,105,115-16,131-32,163-67,171,175-76,178-82$, reprinted in MARBURY VERSUS MADISON, supra note 19, at 310, 310-15 [hereinafter Senate Debate over the Repeal Act]. 
vested. $^{79}$ The text of section 25 of the Judiciary Act empowers the Supreme Court to declare federal and state laws unconstitutional only when reviewing state court decisions. ${ }^{80}$ The Judiciary Act did not explicitly state whether Justices could declare laws unconstitutional when exercising original jurisdiction or adjudicating appeals from the lower federal courts. As further developed in United States $v$. Klein, ${ }^{81}$ Marbury established that courts must consider the Constitution and all other relevant legal sources whenever they exercise jurisdiction. Marshall argued that it was "too extravagant to be maintained" that "a case arising under the [C]onstitution should be decided without examining the instrument under which it arises." 82 Congress, in this view, vests Justices with the power to declare laws unconstitutional whenever it grants courts the jurisdiction necessary to adjudicate particular disputes about that law. The specific language in section 25 authorizing the Supreme Court to sustain state court decisions declaring federal laws unconstitutional was unnecessary. The national legislature may not vest federal courts with jurisdiction to decide a class of cases, while also prohibiting the Justices from relying on some otherwise relevant fact or law. As Chief Justice Salmon Chase declared in Klein, "[T]he legislature may [not] prescribe rules of decision to the Judicial Department of the government in cases pending before it." ${ }^{, 83}$

The Marbury/Klein principle was controversial in 1803. Prominent Jeffersonians challenged the link between jurisdiction and judicial review during the debate over proposed repeal of the Judiciary Act of $1801 .^{84}$ Many insisted that the Supreme Court lacked the power to ignore federal laws when exercising legislatively mandated appellate jurisdiction. "To declare a law null and void," Representative Philip R. Thompson of Virginia declared, "is certainly not such a case, either in law or equity, arising under the Constitution." 85 In Marbury, Chief

\footnotetext{
79 See Marbury v. Madison, 5 U.S. (1 Cranch) 137 (1803).

80 Judiciary Act of 1789 , ch. $20, \S 25$, 1 Stat. 73, 85-86 (1789).

8180 U.S. (13 Wall.) 128 (1871).

82 Marbury, 5 U.S. at 179.

83 Klein, 80 U.S. at 146.

84 See, e.g., Senate Debate over the Repeal Act, supra note 78, at 310-15; 11 ANNALS of CONG. 529-33, 536, 542-44, 552-54, 556-58, 567-68, 574-76, 595-96, 614-15, 645$48,650,661-62,689-91,698-702,727-28,739-41,743,747-48,754-57,759-60,783-$ $87,823-24,826,841-42,859,861,865-66,875,876,879-81,884,903-05,918-32,935$, $940-41,947-48,973,982-83$ (1802), reprinted in MARBURY VERSUS MADISON, supra note 19 , at $315,315-28$.

8511 ANNALS OF CONG. 553 (1802).
} 
Justice Marshall successfully resisted this effort to limit federal judicial authority.

Marbury did not challenge the more important principle that legislatively conferred jurisdiction is a prerequisite to the judicial power to declare laws unconstitutional. In antebellum America, federal jurisdiction existed largely at congressional discretion. Both the Ellsworth and Marshall Courts sapped Marbury of any substantial influence on the legal foundations of judicial power by holding that courts could adjudicate appeals only when federal law permitted the exercise of jurisdiction. In Wiscart v. Dauchy, the Ellsworth Court asserted, "If Congress has provided no rule to regulate our proceedings, we cannot exercise an appellate jurisdiction." ${ }^{86}$ Marshall endorsed this sentiment shortly after handing down Marbury. The "affirmative description" of jurisdiction laid out in the Judiciary Act of 1789, the Court in Durousseau v. United States declared, "has been understood to imply a negative on the exercise of such appellate power as is not comprehended within it."

This restriction of federal judicial power remained good law throughout the Jacksonian era and the Reconstruction. Robert N. Clinton thoroughly documents how "federal judicial authority [under Taney and Chase] was a more fragile creature of statutory grace, owing its life-blood to the largess of Congress." Justices consistently maintained that federal appellate jurisdiction was given by the national legislature and, therefore, could be taken away by the same legislature. "“[T]he disposal of the judicial power (except in a few specified instances) belongs to Congress[,] and Congress is not bound to enlarge the jurisdiction of the Federal courts to every subject, in every form which the Constitution might warrant." " 89 Justice Peter Daniel ruled that "the judicial power of the United States . . . is . . . dependent for its distribution . . . entirely upon the action of Congress." "Co "Congress," his majority opinion

863 U.S. (3 Dall.) 321, 327 (1796).

8710 U.S. (6 Cranch) 307, 314 (1810); see also United States v. Goodwin, 11 U.S. (7 Cranch) 108 (1812) (finding that the Supreme Court has no appellate jurisdiction in the absence of legislation).

88 Robert N. Clinton, A Mandatory View of Federal Court Jurisdiction: Early Implementation of and Departures from the Constitutional Plan, 86 COLUM. L. REV. 1515, 1608 (1986).

89 Sheldon v. Sill, 49 U.S. (8 How.) 441, 449 (1850) (quoting Turner v. Bank of North America, 4 U.S. (4 Dall.) 8, 10 n. 1 (1799)).

90 Cary v. Curtis, 44 U.S. (3 How.) 236, 245 (1845). 
concluded, could "withhold ... jurisdiction from [federal courts] in the exact degrees and character which ... may seem proper for the public good." 91 The Chase Court's decision to forego deciding $E x$ parte $\mathrm{McCardle}{ }^{92}$ while Congress considered stripping jurisdiction was an application of the longstanding principle that federal judicial appellate review existed at legislative whim. ${ }^{93}$

Wiscart and Durousseau reduced Marbury to near-insignificance as an adequate legal foundation for judicial review. Most controversial and politically important Supreme Court decisions before the Civil War were exercises of appellate jurisdiction. Had Congress not provided for federal appellate jurisdiction, Supreme Court Justices, following the Ellsworth and Marshall Court precedents, would have been legally compelled to refrain from handing down constitutional decisions in such cases as Fletcher $v$. Peck, ${ }^{94}$ McCulloch v. Maryland, ${ }^{95}$ Gibbons v. Ogden, ${ }^{96}$ and Dred Scott v. Sandford. ${ }^{97}$ Some doctrine suggests that the Supreme Court's original jurisdiction was also subject to legislative whims. In Marbury v. Madison, the Court held that Congress could not add to the constitutionally prescribed original jurisdiction of the Supreme Court. ${ }^{98}$ Cohens $v$. Virginia permitted state courts to exercise original jurisdiction in cases that Article III established as part of the original jurisdiction of the Supreme Court. ${ }^{99}$ Perhaps Congress could furtherreduce federal judicial power, if it so desired, by first permitting state courts to adjudicate cases in which the Constitution proclaimed the Supreme Court had original jurisdiction and then not vesting federal courts with the power to hear appeals from these local decisions. ${ }^{100}$

\footnotetext{
91 Id.; see also Clinton, supra note 88, at 1589-92.

9274 U.S. (7 Wall.) 506 (1868).

93 See Mark A. Graber, Legal, Strategic or Legal Strategy: Deciding to Decide During the Civil War and Reconstruction, in THE SUPREME COURT AND AMERICAN POLITICAL DEVELOPMENT 33, 34 (Ronald Kahn \& Ken I. Kersch eds., 2006).

9410 U.S. (6 Cranch) 87 (1810).

9517 U.S. (4 Wheat.) 316 (1819).

9622 U.S. ( 9 Wheat.) 1 (1824).

9760 U.S. (19 How.) 393 (1856).

985 U.S. (1 Cranch) $137,174-76$ (1803).

9919 U.S. (6 Wheat.) 264, 394-402 (1821).

100 Cohens was a case that fit this description, and Virginia vigorously objected to federal judicial authority to review that case. A longstanding debate exists over the extent to which Congress may fully strip the Supreme Court of jurisdiction over cases raising constitutional issues. The seminal discussion of this issue is Henry M. Hart, Jr., The
} 
Such a law, which seems consistent with Wiscart, would have effectively fulfilled Mark Tushnet's hope that the Constitution be taken from the Supreme Court ${ }^{101}$ without overruling Marbury. ${ }^{102}$

In conjunction, Wiscart and Marbury help explain why most opponents of judicial review before the Civil War did not complain that federal judicial review, particularly federal judicial review of state laws, was countermajoritarian. ${ }^{103}$ To the extent section 25 of the Judiciary Act provided the crucial legal and political foundations for federal judicial authority, the exercise of that judicial authority was no more countermajoritarian than the exercise of any other statutorily delegated power by an unelected federal official. Legislative majorities opposed either to the trend of judicial decisions or to judicial power in principle could practically abolish federal judicial review by eliminating the appellate jurisdiction of the Supreme Court. Antebellum opponents of judicial authority understood the basic structure of that authority. Most complained about "consolidation," not minority rule. ${ }^{104}$ Their resentments were typically directed at federal power generally and were often expressed after the Supreme Court sustained Federalist or National Republican measures. Senator Robert Hayne observed in his attack on federal judicial power during his famous debates with Daniel Webster: "If the will of a majority of Congress is to be the supreme law of the land, it is clear the [C]onstitution is a dead letter." ${ }^{\text {"105 }}$ Federal review of state legislation subverted constitutional limitations, John C. Calhoun agreed, because "[ $t]$ he judges are, in fact, as truly the judicial representatives of this united majority, as the majority of Congress itself." 106

Recognizing the statutory foundations of federal judicial authority, proponents and opponents of judicial review before the Civil War

Power of Congress to Limit the Jurisdiction of Federal Courts: An Exercise in Dialectic, 66 HARV. L. REV. 1362 (1953).

101 See MARK TUSHNET, TAKING THE CONSTITUTION AWAY FROM THE COURTS 154 76 (1999).

102 See BICKEL, supra note 58, at 13-14 (noting that, to the extent jurisdiction is legislatively conferred, Congress may abolish judicial review by withdrawing jurisdiction).

103 See Barry Friedman, The History of the Countermajoritarian Difficulty, Part One:

The Road to Judicial Supremacy, 73 N.Y.U. L. REV. 333, 405-14 (1998).

104 See Michael J. Klarman, How Great Were the "Great" Marshall Court Decisions?, 87 VA. L. REV. $1111,1142-44$ (2001).

1056 REG. DEB. 88 (1830).

106 John C. Calhoun, Fort Hill Address, in 6 THE Works of JoHn C. CaLhoun 59, 71 (Richard K. Crallé ed., 1864), reprinted in THE NuLlifiCATION ERA: A DOCUMENTARY RECORD 140, 145 (William W. Freehling ed., 1967). 
concentrated their political energies debating the merits of maintaining, repealing, or modifying the Judiciary Act of 1789 . Given that almost every controversial exercise of federal judicial power in antebellum America was an exercise of the Supreme Court's appellate jurisdiction, the judicial power to declare laws unconstitutional could be substantially eviscerated or extended by limiting or increasing this jurisdiction. During the 1820 s, proponents of judicial power sought to expand the federal question jurisdiction of federal courts. ${ }^{107}$ Opponents sought to repeal section $25 .^{108}$ When Joseph Story expressed fears for the survival of judicial power in Jacksonian America, the immediate object of his fear was the growing assault on section 25, not a worry that the Supreme Court would soon be staffed with Justices who would overrule Marbury v. Madison. ${ }^{109}$

II

\section{JUDICIAL POLITICS IN JEFFERSONIAN AMERICA}

Neither Marbury nor section 25 was in serious jeopardy of being overruled or repealed during the Madison, Monroe, and Adams administrations. Thomas Jefferson wrote bitter letters complaining about the federal judiciary, but only after he left the presidency and his influence on national politics-as opposed to politics in Virginia-had waned considerably. State legislators passed resolutions condemning judicial power, and state representatives proposed curbs on federal judicial authority when their state became embroiled in constitutional controversies with the federal judiciary. Congress brushed aside such proposals without serious legislative debate. Many court-curbing measures were sharply condemned by both state legislatures and representatives from states whose cherished policies were not in immediate danger of being declared unconstitutional by federal judges. When local interests were too powerful, either federal judges refrained from striking down state measures or exercises of federal judicial power striking down these measures were not enforced. This combination of political support, judicial restraint, and local noncompliance eased pressures to weaken

107 See Charles Warren, Legislative and Judicial Attacks on the Supreme Court of the United States-A History of the Twenty-Fifth Section of the Judiciary Act (pt. 1), 47 AM.

L. REV. 1, 28 (1913) [hereinafter Warren, Legislative and Judicial Attacks (pt. 1)].

108 See id. at 27-28; see also infra notes 179, 196 and accompanying text.

109 See Letter from Joseph Story to Professor Ticknor (Jan. 22, 1831), in 2 LIFE AND LETTERS OF JOSEPH STORY 48, 48-49 (William W. Story ed., 1851). 
the constitutional or statutory foundations of judicial authority during the first quarter of the twentieth century.

Judicial power in Jeffersonian America seemed to rest on politically weak foundations, even after Jefferson left the presidency. Jefferson remained a revered political figure in retirement. He frequently urged his supporters to challenge the pretensions of the Marshall Court. "[A]fter twenty years' confirmation of the federated system by the voice of the nation, declared through the medium of elections," the sage of Monticello bemoaned in 1819, "the judiciary on every occasion [is] still driving us into consolidation." 110 Hardly a year passed without some state government or prominent state official calling for the repeal of section 25 or for a constitutional amendment curbing federal judicial authority. Pennsylvania in $1809,{ }^{11}$ Ohio in $1821,{ }^{12}$ Virginia in $1821^{113}$ and $1829,{ }^{114}$ Kentucky in $1823^{115}$ and

110 Letter from Thomas Jefferson to Judge Spencer Roane (Sept. 6, 1819), in 15 THE WRITINGS OF THOMAS JeFFERSON 212, 212 (Andrew A. Lipscomb ed., 1903); see also Letter from Thomas Jefferson to James Bowdoin (Apr. 2, 1807), in 11 THE WRITINGS OF THOMAS JEFFERSON 183, 186 (Andrew A. Lipscomb ed., 1903); Letter from Thomas Jefferson to Caesar A. Rodney (Sept. 25, 1810), in 12 THE WRITINGS OF THOMAS JEFFERSON 424, 424 (Andrew A. Lipscomb ed., 1903); Letter from Thomas Jefferson to Albert Gallatin (Sept. 27, 1810), in 12 WRITINGS OF JEFFERSON, supra, at 427, 427; Letter from Thomas Jefferson to Albert Gallatin (Aug. 2, 1823), in 12 THE WORKS OF THOMAS JEFFERSON 299, 299-300 (Paul Leicester Ford ed., 1905); Letter from Thomas Jefferson to James Madison (Oct. 15, 1810), in 3 THE REPUBLIC OF LETTERS: THE CORRESPONDENCE BETWEEN THOMAS JEFFERSON AND JAMES MADISON 1776-1826, at 1646, 1646-47 (James Morton Smith ed., 1995); Letter from Thomas Jefferson to Robert J. Gamett (Feb. 14, 1824), in 16 THE WRITINGS OF THOMAS JEFFERSON 14, 14-16 (Andrew A. Lipscomb ed., 1903); Letter from Thomas Jefferson to Samuel H. Smith (Aug. 2, 1823), in 12 WORKS OF JEFFERSON, supra, at 300, 301; Letter from Thomas Jefferson to Judge William Johnson (Mar. 4, 1823), in 12 WORKS OF JEFFERSON, supra, at 277, 279; Letter from Thomas Jefferson to Henry Dearborn (Oct. 31, 1822), in 12 WORKS OF JEFFERSON, supra, at 264, 264-65. Other Old Republicans voiced similar concems. See Spencer Roane, Hampden Essays, RICH. ENQUIRER (June 11-22, 1819), reprinted in JOHN MARSHALL'S DEFENSE OF MCCULLOCH V. MARYLAND 106, 151 (Gerald Gunther ed., 1969); Somers, Examination of the Opinion of the Supreme Court in the Case of Cohens vs. The State of Virginia, RICH. ENQUIRER, May 15, 1821.

111 Resolution of the Legislature of Pennsylvania, April 3, 1809, in STATE DOCUMENTS ON FEDERAL RELATIONS: THE STATES AND THE UNITED STATES 46, $46-48$ (Herman V. Ames ed., 1906) [hereinafter STATE DOCUMENTS].

112 Extracts from the Report and Resolutions of Ohio Relative to the Bank and the Powers of the Federal Judiciary (Jan. 3, 1821), in STATE DoCUMENTS, supra note 111, at 93, 93-101.

113 Virginia on Jurisdiction of the Federal Courts (Feb. 19, 1821), in STATE DOCUMENTS, supra note 111, at 103, 103.

114 Resolutions of Virginia (Feb. 24, 1829), in STATE DOCUMENTS, supra note 111, at 156, 156-57. 
$1824,{ }^{116}$ Georgia in $1827,{ }^{117}$ and South Carolina in $1827^{118}$ directly challenged federal judicial power to strike down their respective laws and policies. Both the threat and practice of federal judicial authority brought forth strong state protest. Shortly before the U.S. Supreme Court handed down Cohens v. Virginia, the Virginia state legislature passed a resolution rejecting federal authority to review state court decisions. ${ }^{119}$ Representative Richard Johnson of Kentucky responded to Green v. Biddle by proposing a constitutional amendment limiting federal appellate jurisdiction. ${ }^{120}$ Many prominent representatives made long speeches in Congress condemning the Marshall Court. Senator Martin Van Buren of New York, in one of the more restrained polemics against judicial power, suggested that "the people of the States might with safety be left to their own legislatures and the protection of their own courts." ${ }^{\prime 21}$

These complaints against federal judicial authority, however frequent, caustic, and uncompromising, did not represent mainstream National Republican sentiment, particularly during the "golden era of the Marshall Court" from 1810 to 1824. President James Madison pointedly ignored Jefferson's advice when appointing the nationalist Joseph Story to the Supreme Court. ${ }^{122}$ The main journalistic organ of the Madison administration described the Supreme Court as "a branch of the government which it is important to hold in due veneration."123 Some state legislatures responded to attacks on section 25 by passing resolutions supporting federal appellate jurisdiction. When

115 Extract from Preamble and Resolutions of the Legislature (Dec. 29, 1823), in STATE DOCUMENTS, supra note 111, at 107, 107.

116 Remonstrance of the Legislature of Kentucky (Jan. 7, 1824), in STATE DOCUMENTS, supra note 111 , at $108,108-10$.

117 Extract from Letter of Governor Troup to the Senators and Representatives of Georgia in Congress of the United States (Feb. 21, 1827), in STATE DoCUMENTS, supra note 111, at 122, 122-23; Extract from Report of the Legislature of Georgia Commending the Course of Governor Troup (Dec. 24, 1827), in STATE DocUMENTS, supra note 111, at $123,123-24$.

118 South Carolina and the Harrisburg Convention (Dec. 19, 1827), in STATE DOCUMENTS, supra note 111 , at 144, 144-45.

119 Virginia on Jurisdiction of the Federal Courts, supra note 113, at 103-04; see Warren, Legislative and Judicial Attacks (pt. 1), supra note 107, at 16-17.

120 Warren, Legislative and Judicial Attacks (pt. 1), supra note 107, at 26-28, 30-33.

121 Id. at 32. For other examples of speeches attacking judicial authority, please see those of Senator John Rowan of Kentucky. Id.

122 See ABRAHAM, supra note 38, at 72.

123 The Supreme Court, DAILy NAT'L INTElligenCER (Wash., D.C.), Feb. 24, 1814; see also JEAN EDWARD SMITH, JOHN MARSHALL: DEFINER OF A NATION 419 (1996). 
Pennsylvania questioned judicial authority in $1809,{ }^{124}$ the Virginia state legislature declared that the Supreme Court of the United States was "more eminently qualified ... to decide [disputes between states and the national government] than any other tribunal which could be [created]." ${ }^{25}$ In 1822, the Massachusetts state legislature proclaimed, "The Supreme Court of the United States [is] the ultimate tribunal for the determination of all cases arising under the Constitution and laws of the United States."126 State resolutions supporting federal courts spoke the language of judicial supremacy. "[I]t belongs to the judicial department to determine all cases arising from a conflict between the laws of the United States and the laws of a particular State," the state legislature of Massachusetts asserted. ${ }^{127}$ State legislators added, "[T]he constitutional exercise and preservation of the judicial power of the United States is essential to the safety and prosperity of the Union." 128 Many members of Congress rushed to the defense of the federal judiciary when proposals were made to restrict judicial review. "We say that the Supreme Court is like unto a majestic tree," Representative Clement Dorsey of Maryland proclaimed in 1826, "shooting its roots through, and deriving its sustenance from, all the surrounding soil, by which it has attained full vigor; putting forth its foliage and branches, under which the American People repose with confidence and safety." Congressman Willie P. Magnum of North Carolina less metaphorically praised the "profound learning," "pure intellect," and "incorruptible integrity" of the Justices in a speech that insisted the Supreme Court was the "last hope of this country."130

Early nineteenth-century Supreme Court practice eased initial fears that unelected Justices would unduly interfere with national majorities. The Marshall Court made no effort to beat down and erase the works of republicanism. With the exception of Justice John

124 Resolution of the Legislature of Pennsylvania, April 3, 1809, supra note 111, at 46, 46.

125 Reply of the General Assembly of Virginia to Pennsylvania (Jan. 26, 1810), in STATE DOCUMENTS, supra note 111 , at $49,49$.

126 Reply of Massachusetts to Ohio (Feb. 7, 1822), in STATE DOCUMENTS, supra note 111 , at $101,101-02$.

127 Id. at 102.

$128 \mathrm{Id}$. at $102-03$.

1292 REG. DEB. 957 (1826).

1302 REG. DEB. 937, 944 (1826). 
Marshall's ruling during the Burr trial, ${ }^{131}$ from 1800 until 1828 the Supreme Court did not challenge any national initiative. Federalist Justices were constitutionally powerless to interfere with Jeffersonian policies aimed at retrenchment. "Judicial review," Whittington observes, "is more useful for hampering the expansion of government than for hampering the reduction of government, regardless of any policy disagreements between the Court and the elected branches."132 Jefferson opposed constitutionally controversial exercises of national power, such as incorporating a national bank and federal restrictions on seditious speech. Federalists, who thought these programs constitutionally permissible, did not insist they were also constitutionally necessary. When Jefferson allowed the Sedition Act to expire and his successors initially refused to recharter the national bank, not even the most committed Hamiltonian thought the Supreme Court could reinstitute Federalist policies. The Marshall Court could pointedly inform James Monroe that the decision in McCulloch $v$. Maryland committed the Justices to sustaining all federally funded internal improvements. ${ }^{133}$ No judicial remedy existed when Monroe vetoed the Bonus Bill on constitutional grounds. ${ }^{134}$

Federal Justices mitigated potential tensions with Jeffersonian officials by pulling punches when political antagonisms were perceived as too intense. The Marshall Court did not declare the Repeal Act of 1802 unconstitutional $^{135}$ or order Thomas Jefferson to deliver a judicial commission to William Marbury, ${ }^{136}$ even though most Federalists who were not on the Court thought both claims had constitutional merit. ${ }^{137}$ After consistently supporting the policies of

131 For the political response to the Burr trial, see Thomas Jefferson, Seventh Annual Message, in 1 A COMPILATION OF THE MESSAGES AND PAPERS OF THE PRESIDENTS 413, 423-25 (James D. Richardson ed., 1897); GEORGE LEE HASKINS \& HERBERT A. JOHNSON, FOUNDATIONS OF POWER: JOHN MARSHALL, 1801-1815, at 289-91 (1981).

132 WhitTINGTON, supra note 16, at 43-44; see also Mark A. Graber, The Jacksonian Origins of Chase Court Activism, 25 J. SUP. CT. HIST. 17 (2000).

1331 WARREN, THE SUPREME COURT, supra note 3, at 81.

134 James Monroe, Veto Message, in 2 A COMPILATION OF THE MESSAGES AND PAPERS OF THE PRESIDENTS 711, 711-12 (James D. Richardson ed., 1897).

135 See Stuart v. Laird, 5 U.S. (1 Cranch) 299 (1803).

136 See Marbury v. Madison, 5 U.S. (1 Cranch) 137 (1803).

137 See 12 ANNALS OF CONG. 30-31, 51-52 (1803); 12 ANNALS OF CONG. 34, 35-37, 40, 42, 44, 46-50 (1803), reprinted in MARBURY VERSUS MADISON, supra note 19, at 335, 335-38. Marshall apparently agreed. See Ruth Wedgwood, Cousin Humphrey, 14 CONST. COMMENT. 247 app. at 268 (1997) (reprinting Letter from John Marshall to Henry Clay (Dec. 22, 1823)). 
the Adams administration during the undeclared war on France, ${ }^{138}$ the Supreme Court made decisions more consistent with the Republican Party after Jefferson took office. ${ }^{139}$ Federalists in the Massachusetts state legislature declared Jefferson's embargo unconstitutional, ${ }^{140}$ but the Federalist judicial appointee serving in Massachusetts sustained the measure. ${ }^{141}$ On dubious legal grounds, the Marshall Court sustained a Virginia law outlawing the national lottery, ${ }^{142}$ even though the state measure was arguably identical, in all relevant respects, to the Maryland statute declared unconstitutional in McCulloch. ${ }^{143}$ John Marshall, while riding circuit in Virginia, found legal excuses to avoid declaring a Virginia law prohibiting free sailors of color from entering the state unconstitutional. "[A]s I am not fond of butting against a wall in sport," he informed Joseph Story, "I escaped on the construction of the act."144

The limited pressures to restrict judicial power during the early Republic were also alleviated by officials' tendencies to ignore federal court rulings that "gored too many local oxen." Leslie Goldstein found "a steady stream of intermittent but fierce resistance from states in all parts of the country" to federal judicial authority. ${ }^{145}$ The claimants in Fletcher v. Peck were not immediately compensated

138 See Bas v. Tingy, 4 U.S. (4 Dall.) 37 (1800); 1 WARREN, THE SuPREME COURT, supra note 3 , at $156-67$.

139 See Little v. Barreme, 6 U.S. (2 Cranch) 170 (1804); United States v. Schooner Peggy, 5 U.S. (1 Cranch) 103 (1801); Talbot v. Seeman, 5 U.S. (1 Cranch) 1 (1801). See generally Mark A. Graber, Establishing Judicial Review? Schooner Peggy and the Early Marshall Court, 51 POL. RES. Q. 221 (1998).

140 See Resolutions of the Enforcement Act, February 15, 1809, in STATE DOCUMENTS, supra note 111, at 34, 34-35; see also Report and Resolutions of Rhode Island on the Embargo (Mar. 4, 1809), in STATE DoCUMENTs, supra note 111 , at 42, 42-43; Resolutions of the General Assembly (Feb. 23, 1809), in STATE DOCUMENTS, supra note 111 , at $40,40-41$.

141 United States v. The William, 28 F. Cas. 614 (D. Mass. 1808) (No. 16,700).

142 Cohens v. Virginia, 19 U.S. (6 Wheat.) 264, 442-47 (1821).

143 Mark A. Graber, The Passive-Aggressive Virtues: Cohens v. Virginia and the Problematic Establishment of Judicial Review, 12 CONST. COMMENT. 67, 83-87 (1995).

144 See 1 WARREN, THE SUPREME COURT, supra note 3, at 626 (quoting Letter from John Marshall to Joseph Story (Sept. 26, 1823)). The case in question is probably Brig Wilson' $v$. United States (C.C.D. Va. 1820), reprinted in 9 THE PAPERS OF JOHN MARShALL 31, 31-40 (Charles F. Hobson ed., 2000); see also DWIGHT WILEY JESSUP, REACTION AND ACCOMMODATION: THE UNITED STATES SUPREME COURT AND POLITICAL Conflict, 1809-1835, at 281 n.178 (Harold Hyman \& Stuart Bruchey eds., 1987).

145 LESLIE FriedMan GoldsteIN, CONSTITUTING FEDERAL SOVEREIGNTY: THE ELROPEAN UNION N COMPARATIVE CONTEXT 32 (2001); see also id. at 24-29 tbl.3. 
after their judicial victory. The dispossessed land speculators only received some redress by federal legislation that provided sums far less than the full value of the disputed property in $1815 .{ }^{146}$ Green $v$. Biddle had almost no influence on Kentucky land policies. ${ }^{147}$ South Carolina continued banning free sailors of color despite a contrary federal court ruling. ${ }^{148}$ Left free to maintain policies struck down by federal courts, local politicians did not actively pursue demands that federal judicial authority be curbed. Ruth Wedgwood observes that "attacks [by Kentucky] upon the Supreme Court in the 1820s never led to any radical restriction of the Court's jurisdiction, in part because the Court acquiesced in the parties' disobedience." 149

National political figures rarely made efforts to enforce Supreme Court decisions in the face of local hostility. The Monroe and Adams administrations displayed no more enthusiasm for enforcing the rights of free sailors of color in the South than the Marshall Court did. Attorney General William Wirt issued an opinion declaring state prohibitions unconstitutional, ${ }^{150}$ but no effort was made to implement that decree. $^{151}$ Land claimants in Kentucky received no federal legislative or executive assistance in obtaining actual possession of their judicially granted property rights. Early nineteenth-century state officials, with federal acquiescence, failed to comply with federal court orders so frequently that some recalcitrant states questioned whether any obligation existed to implement federal judicial decisions. Ohio legislators, committed to taxing the national bank after $\mathrm{McCulloch}$, asked how, in light of the general disrespect for judicial rulings at the time, their state could "be condemned because she did not abandon her solemn legislative acts as a dead letter upon the promulgation of an opinion of that tribunal[?]"152

\footnotetext{
146 Alexander Hamilton's Opinion on the Georgia Repeal Act (Mar. 25, 1795), reprinted in C. Peter Magrath, Yazoo: Law and Politics IN THE NeW Republic app. D, at 149-50 (1966).

147 See JESSUP, supra note 144, at 221-31.

148 Elkison v. Deliesseline, 8 F. Cas. 493 (C.C.D.S.C. 1823) (No. 4,366); Paul Finkelman, States' Rights North and South in Antebellum America, in AN UNCERTAIN TRADITION: CONSTITUTIONALISM AND THE History OF THE SOUTH 125, 132-33 (Kermit L. Hall \& James W. Ely, Jr., eds., 1989); William J. Rich, Lessons of Charleston Harbor: The Rise, Fall and Revival of Pro-Slavery Federalism, 36 MCGEORGE L. REV. 569, 58182 (2005).

149 Wedgwood, supra note 137 , at 266.

150 Validity of the South Carolina Police Bill, 1 Op. Att'y Gen. 659 (1824).

151 See Finkelman, supra note 148, at 132-33; Rich, supra note 148, at 581-82.

15237 ANNALS OF CONG. app. at 1697 (1821).
} 
The most important Supreme Court decisions handed down during the "Golden Age" of the Marshall Court sustained policies preferred by the dominant National Republican coalition, in spite of opposition confined to particular localities. ${ }^{153}$ McCulloch $v$. Maryland held that both Congress and President Madison acted constitutionally when incorporating a national bank in the wake of the War of 1812 . While $\mathrm{McCulloch}$ was pending, large congressional majorities rejected an effort to repeal the national bank. The official newspaper of the Monroe administration immediately endorsed the Marshall Court's decision. ${ }^{154}$ Fletcher $v$. Peck held that prominent New England members of the Jeffersonian coalition could not be divested of their property rights when the Yazoo scandal broke in Georgia. Marshall's decision, Peter Magrath notes, "was in nearly perfect harmony with the attitudes and values of most politically conscious Americans."155 Hardly any prominent politician inside or outside of New York favored the Livingston monopoly that was declared unconstitutional in Gibbons v. Ogden. ${ }^{156}$ The Court in Green v. Biddle took the side of Virginia, the more powerful state, in a series of land disputes with Kentucky. ${ }^{157}$

Not surprisingly, given the trend of its decisions, the Marshall Court enjoyed warm relations with leading National Republican elected officials and opinion-makers. James Madison defended judicial power. ${ }^{158}$ James Monroe and John Marshall enjoyed a lifelong friendship. ${ }^{159}$ John Quincy Adams regarded Marshall's

\footnotetext{
153 For a more detailed discussion of the argument in this paragraph, see Mark A. Graber, Federalist or Friends of Adams: The Marshall Court and Party Politics, 12 STUD. AM. POL. DEV. 229 (1998).

154 See Daily NaT'L INTELLIGeNCER (Wash., D.C.), Mar. 13, 1819, at 3; see also 1 WARREN, THE SUPREME COURT, supra note 3, at 509-10.

155 MAGRATH, supra note 146, at 114.

156 See JESSUP, supra note 144, at 291-92 ("[T] he Gibbons decision proved generally popular even in New York.”); 1 WARREN, THE SUPREME COURT, supra note 3, at 598 (noting that Attorney General William Wirt, in his private capacity, argued against the steamship monopoly); Wallace Mendelson, New Light on Fletcher v. Peck and Gibbons v. Ogden, 58 YALE L.J. 567, 567 (1949).

157 See Francis N. STITES, Private Interest and Public Gain: The Dartmouth COllege CASE, 1819, at 138 (1972); Paul W. Gates, Tenants of the Log Cabin, 49 MISS. VALLEY HIST. REV. 3, 19-21 (1962).

158 SMITH, supra note 123, at 374 ("Under Madison, a rapprochement between the executive and the judiciary was quickly achieved."); Letter from James Madison to Thomas Jefferson (June 27, 1823), in 9 THE WRITINGS OF JAMES MADISON 137, 140-43 (Gaillard Hunt ed., 1910).

159 See R. KeNT NEWMYER, JOHN MARSHALl AND THE HEROIC AGE OF THE SUPREME COURT 7, 463 (2001).
} 
appointment as his father's greatest gift to the country. ${ }^{160}$ Prominent National Republicans sought to exploit the close ideological affinities between both judicial and elected majorities by proposing measures that would expand the federal court system. ${ }^{161}$ Judicial power was more often celebrated than condemned during the ensuing debates over these measures. In 1826, Daniel Webster asserted that the federal judiciary "has been found to fulfil [sic], so far, so well, and for so long a time, the great purposes which it was designed to accomplish." 162 Is the Supreme Court "not adorned by great and illustrious merit?" Charles Mercer of Virginia inquired. ${ }^{163}$ "Are not all its decisions stamped with the most undeviating rectitude?" "164 The Daily National Intelligencer, a National Republican organ, declared that "[i]n our whole political system, there is nothing more valuable than the Judiciary, by the aid of which, whilst the powers of the Government are asserted, the rights of the several States, as well as of individuals, are upheld and maintained." 65 "[T]he Judiciary Act," the editors continued, "is almost as sacred as the Constitution itself, and should be approached with nearly the same reverence."166

This broad support from the elite for federal judicial authority suggests the "Revolution of 1800" existed primarily in Jefferson's mind. The better metaphor is that of Joseph Ellis's Founding Brothers. ${ }^{167}$ From 1789 until 1828, the United States was governed largely by the persons, or the protégés of the persons, who declared independence, fought the American Revolution, and supported the Constitution of 1789. While familial differences existed among the first generation, they shared certain basic commitments. One of those commitments was the sort of aristocratic republic in which the federal judiciary was bound to play a significant role. ${ }^{168}$ As Ran Hirschl

160 Diary Entry of John Quincy Adams (Feb. 9, 1846), in 12 MEMOIRS OF JOHN QUINCY ADAMS, COMPRISING PORTIONS OF HIS DIARY FROM 1795 TO 1848, at 242, 243 (Charles Francis Adams ed., 1877).

161 See Curtis Nettels, The Mississippi Valley and the Federal Judiciary, 1807-1837, 12 Miss. VALLEY HIST. REV. 202, 213-15 (1925).

1622 REG. DEB. 873 (1826).

1632 REG.DEB. 907 (1826).

164 Id.

165 The Judiciary, DAILY NAT'L INTELLIGENCER (Wash., D.C.), Jan. 5, 1826, at 3.

166 Id.

167 See generally JOSEPH J. ElLIS, FOUNDING BROTHERS: THE REVOLUTIONARY GENERATION (2000).

168 See GoRDON S. WOOD, THE RADICALISM OF THE AMERICAN REVOLUTION 323-25 (1991). 
suggests in reference to other countries, first-generation judicial review helped a somewhat weakened elite protect certain liberal property rights from populist legislative impulses. ${ }^{169}$ While antijudicial populists controlled some state legislatures-and often had the power to block federal legislation aimed at further empowering federal courts, Republican elites, before 1828, maintained sufficient control over the national government to guarantee that any attack on the Supreme Court or other federal court decision would largely be an 'effort in symbolic politics, which was more likely to win political support at home than actually influence judicial authority. ${ }^{170}$

Political fragmentation contributed significantly to federal judicial authority. On some matters, most notably McCulloch $v$. Maryland ${ }^{171}$ and Gibbons v. Ogden, ${ }^{172}$ the Marshall Court promoted national policies in the hinterlands. ${ }^{173}$ On other matters, most notably Dartmouth College v. Woodward and Green v. Biddle, the Marshall Court adjudicated controversies that, for various reasons, did not generate strong passions outside of the states involved. Daniel Webster, in Dartmouth College, famously proclaimed, "It is . . a small College ... yet there are those who love it,"174 but the number of politically active citizens throughout the nation interested in the politics of that institution was minute. ${ }^{175}$ When adjudicating such matters of low political salience, federal courts engage in constitutional policymaking that cannot neatly be encapsulated either as countermajoritarian or as advancing the policies preferred by clear, dominant majorities. ${ }^{176}$ While some states complained bitterly about a particular judicial decision, others were either supportive or indifferent. State positions on the abstract merits of federal judicial authority varied with the issues that had most recently been before federal courts. ${ }^{177}$ Virginians opposed judicial supremacy both during

\footnotetext{
169 See HIRSCHL, supra note 7, at 108; Graber, Constructing Judicial Review, supra note 59 , at 433 .

170 See Stephen M. Engel, 'A Mere Party Machine'?: Judicial Authority, Party Development, and the Changing Politics of Attacking the Courts (2009) (unpublished Ph.D. dissertation, Yale University) (on file with author).

17117 U.S. (4 Wheat.) $316(1819)$.

17222 U.S. (9 Wheat.) 1 (1824).

173 See Graber, supra note 153, at 252-59.

174 Rufus Choate, A Discourse Commemorative of Daniel Webster (July 27, 1853), in 1 WORKS OF RUFus CHOATE 493, 516 (Samuel G. Brown ed., 1862) (emphasis in original).

175 See 1 WARREN, THE SUPREME COURT, supra note 3, at 475.

176 See WHITTINGTON, supra note 16, at 120-24.

177 See MCCLOSKEY, supra note 75, at 38.
} 
the debates over the Sedition Acts and while Cohens was being litigated. ${ }^{178}$ Conversely, representatives from Virginia both supported federal judicial authority during debates over the Embargo Act and issued no public statement on the matter when Green $v$. Biddle was litigated. ${ }^{179}$ This inconstancy was hardly conducive to the formation of the relatively stable coalitions necessary to curb federal judicial authority.

During the first quarter of the nineteenth century, the structure of constitutional politics enabled federal Justices to assert their particular constitutional visions aggressively. When defending policies supported by prominent National Republicans, Marshall Court Justices consistently advanced constitutional claims that were bolder than necessary to resolve the case. In $\mathrm{McC}$ Culloch, most notably, Marshall relied heavily on notions of federal power that James Madison thought too "latitudinary." 180 President Monroe's conception of federal commerce power was considerably narrower than that advanced in Gibbons v. Ogden. ${ }^{181}$ These jurisprudential differences, however, had limited practical consequences before Andrew Jackson took office. Members of the National Republican coalition who questioned the logic of McCulloch and Gibbons nevertheless supported the results in those cases ${ }^{182}$ and, more significantly, remained free to act on more limited notions of national authority when making other constitutional decisions. ${ }^{183}$

Political fragmentation proved a mild curse, as well as a blessing, to the Marshall Court and to its political supporters. Federal courts in Jeffersonian America declared state laws unconstitutional without risking legal, political, or personal retaliation, but the diffusion of political power in the early United States proved an obstacle to other facets of judicial authority. A federal government with a fairly weak

178 See Virginia on Jurisdiction of the Federal Courts (Feb. 19, 1821), supra note 113, at 103-04.

179 Reply of the General Assembly of Virginia to Pennsylvania, supra note 125 , at 49 . When the Virginia legislature protested against federal, internal improvements legislation in 1826 and 1827 , the legislative resolves did not include a discussion of judicial power. Resolutions of Virginia, March 6, 1827, in STATE DOCUMENTS, supra note 111, at 142, 142.

180 See Letter from James Madison to Spencer Roane (Sept. 2, 1819), in 8 THE WRITINGS OF JAMES MADISON 447, 447-53 (Gaillard Hunt ed., 1908).

181 See generally James Monroe, in 2 A COMPILATION OF THE MESSAGES AND PAPERS OF THE PRESIDENTS, supra note 134, at 742-83.

1821 WARREN, THE SUPREME COURT, supra note 3, at 517-18, 611-14.

183 See supra notes $132-33$ and accompanying text. 
presence in the states could not enforce most federal court decisions, particularly when all three elected institutions of the national government did not agree with the constitutional claims underlying the decision. ${ }^{184}$ Divided government also inhibited efforts to expand federal judicial authority during the 1820s. General agreement existed that this judicial system should be extended to new Western states. Nevertheless, judicial authority remained stagnant as the House and Senate could not agree on a common proposal. National Republicans from different regions disputed how federal judicial circuits should be allocated between the states, and the ranks of those who disputed any particular allocation would be joined by Old Republicans who opposed any augmentation of federal power in any sense. $^{185}$

III

\section{THE JACKSONIAN CHALLENGE AND THE BUCHANAN RESPONSE}

More serious threats to the political foundations of federal judicial authority emerged after the presidential election of 1828 . Most scholars regard the incoming Jacksonian coalition as hostile to judicial power, particularly as wielded by the Marshall Court. Richard Longaker observes, "Respect for the Marshall court was not a part of the Jacksonian creed." 186 "The Jacksonians," he states, "were vigorous critics of the federal judiciary, and Jackson's election in 1828 was in part a popular repudiation of the institutional aggrandizement of the judicial branch." 187 Opponents of the federal judiciary, long on the periphery of National Republican politics, became important members of the dominant national coalition. Amos Kendall, who played a leading role in anti-Court fights in Kentucky, was a prominent member of Jackson's inner circle. ${ }^{188}$ The Southern bent of the Jacksonian coalition empowered those slave states that, for the past fifteen years, were the center of anti-federal court sentiment. Some commentators hailed Jackson's election as beginning the process that would bring about the repeal of section 25 . "If . . Gen.

\footnotetext{
184 See supra notes $145-52$ and accompanying text.

185 Nettels, supra note 161 , at 221-24.

186 Richard P. Longaker, Andrew Jackson and the Judiciary, 71 POL. SCI. Q. 341, 341 (1956).

$187 \mathrm{Id}$.

188 See Theodore W. Ruger, "A Question Which Convulses a Nation": The Early Republic's Greatest Debate About the Judicial Review Power, 117 HARV. L. REV. 826, 886-87 (2004).
} 
Jackson . . . shall be elected," "An Independent Kentuckian" predicted, "[t]hen the Judiciary Act of Congress, of 1789, shall be repealed."

Several events augured the possible fall of the federal judiciary. Georgia executed George Tassels for murder, even though he had obtained a writ of error from the Supreme Court, which would have allowed him to obtain a ruling on the constitutionality of his state trial. ${ }^{190}$ Lest those actions be subject to misinterpretation, the Georgia state legislature passed resolutions declaring that the Supreme Court had no authority to declare state laws unconstitutional. ${ }^{191}$ President Jackson seemingly sided with Georgia when the Supreme Court, in Worcester v. Georgia, ${ }^{192}$ rejected state efforts to exercise jurisdiction over Native American soil. Jackson may never have said, "John Marshall has made his decision, now let him enforce it," but he made no effort to implement the federal judicial decree. ${ }^{193}$ For the first time since the Repeal Act of 1802, the House of Representatives seriously considered a bill that would weaken the federal judicial authority to declare laws unconstitutional in 1829. In 1831, the House Judiciary Committee called on the national legislature to repeal section 25 of the Judiciary Act. The majority report, written by Representative Warren Davis of South Carolina, declared that congressional "investigation has resulted in a solemn conviction that the twenty-fifth section . . . is unconstitutional." 194 John Marshall regarded these events as the first shots in the battle that would eventually destroy the authority of federal courts. ${ }^{195}$ "The crises of our [C]onstitution is now upon us," he informed Joseph Story. ${ }^{196}$ "A strong disposition to prostrate the judiciary has shown itself," he continued, "and has succeeded to a considerable extent."197

189 "An Independent Kentuckian," The Clay Party, LOUISVILle PUB. AdVERTISER, July 16,1828 .

190 See 1 WARREN, THE SUPREME COURT, supra note 3, at 732-34.

191 See Resolutions of the Legislature Relative to the Case of George Tassels (Dec. 22, 1830), in STATE DOCUMENTS, supra note 111, at 127, 127-28.

19231 U.S. (6 Pet.) 515 (1832).

193 Graber, supra note 153, at 260-61.

194 Report Upon the Judiciary, 7 REG. DEB. app. at lxxvii (1831).

195 See Letter from John Marshall to Joseph Story (Jan. 8, 1830), in 11 THE PAPERS OF JoHN MARSHALl 332, 332-33 (Charles F. Hobson ed., 2002).

$196 \mathrm{Id}$. at 332.

197 Id. 
Justice Marshall's forebodings are better explained by the pessimism of old age ${ }^{198}$ than actual political events. The federal judiciary easily weathered the storms of Jackson's first term. Pressured by the Jackson administration, Georgia settled the most important case concerning the rights of persons on Cherokee lands. ${ }^{199}$ Attacks on federal jurisdiction were parried by overwhelming procourt majorities in Congress. The House report urging the repeal of section 25 was resoundingly rejected, without debate, by a vote of 138-51. ${ }^{200}$ James Buchanan's Counter Report defending federal judicial power is regarded as one of the most influential documents in American history. ${ }^{201}$

\section{A. Weak Attacks, Strong Responses}

Seen in historical context, Georgia's defiance of federal judicial power did not represent a new threat to the Court's authority. From 1789 until 1828, states routinely defied federal judicial orders. ${ }^{202}$ While President Jackson almost certainly disagreed with the Marshall Court's decision in Worcester v. Georgia, his unwillingness to aggressively implement that judicial decision was similar to National Republican unwillingness to either implement Green v. Biddle and Fletcher v. Peck or challenge slave state bans on free sailors of color. ${ }^{203}$ The national inability to enforce judicial decisions, before the Civil War, is better explained by the relatively weak American national state than by any hostility to judicial power. Jackson thought the Supreme Court's decision in Worcester was unenforceable, with or without federal executive support. "[I]f orders were issued tomorrow one regiment of militia could not be got to march to save them from destruction," he informed a correspondent, "and if a colision [sic] was to take place between them and the Georgians, the arm of the government is not sufficiently strong to preserve them from destruction." 204 Jackson's passivity during the Cherokee crisis may also have been part of an effort to preserve judicial power for the

198 See MCCLOSKEY, supra note 75, at 50.

199 RICHARD E. ELLIS, THE UNION AT RISK: JACKSONIAN DEMOCRACY, STATES' RIGHTS, AND THE NULLIFICATION CRISIS 112-20 (1987).

2007 REG. DEB. 542 (1831).

201 See supra notes 29-30 and accompanying text.

202 See GOLDSTEIN, supra note 145, at 23-33.

203 See supra notes 145-52 and accompanying text.

204 Letter from Andrew Jackson to John Coffee (Apr. 7, 1832), in 4 CORRESPONDENCE OF ANDREW JACKSON 429, 430 (John Spencer Bassett ed., 1929). 
conflict over nullification looming with South Carolina-a conflict during which Jackson would call on the national judiciary. for support. ${ }^{205}$ Aware that the national government had a stake in both appeasing Georgia and maintaining the authority of federal courts, Jackson pushed Georgians to settle the dispute over Cherokee lands, so as to leave federal judicial authority unchallenged during the impending nullification debates with South Carolina. ${ }^{206}$

The proposal to repeal section 25 of the Judiciary Act of 1789 was strictly a southern Jacksonian measure, influenced by the Supreme Court's confrontation with Georgia, the looming confrontation with South Carolina, the increased sectionalism of American politics, and the machinations of a Speaker of the House who had long been a foe of the Marshall Court. By the time Jackson assumed the presidency, attacks on federal judicial power from free states had largely ceased. Virtually all proposals to narrow federal jurisdiction were made by representatives from those slave states that either had recently suffered defeats in the Supreme Court, anticipated suffering defeats in the very near future, or feared that Marshall Court decisions could be used to emancipate slaves. ${ }^{207}$ Jackson's victory brought these Southerners into the dominant national coalition. Andrew Stephenson, a southern Jacksonian from Virginia, was elected Speaker of the House. Stephenson, who had proposed curbing federal judicial power during the $1820 \mathrm{~s},{ }^{208}$ packed the House Judiciary Committee with representatives from those slave states that were most hostile to the existing federal court system. ${ }^{209}$ More than fiftyfive percent of House members at that time represented free states, but five of the seven representatives appointed to the Judiciary Committee hailed from the south. ${ }^{210}$ Four of the members-Warren R. Davis of South Carolina, Thomas F. Foster of Georgia, William F. Gordon of Virginia, and Henry Daniel of Kentucky - represented the only four states experiencing conflict with federal courts. ${ }^{211}$ Those four members endorsed the majority report calling for the repeal of

205 ELLIS, supra note 199, at 112-20.

206 See id. at 117.

207 See Warren, Legislative and Judicial Attacks (pt. 1), supra note 107, at 26-34.

208 See id. at 27.

209 See H.R. Jour., 21 st Cong., 2d Sess. 34 (Dec. 9, 1830).

$210 \mathrm{Id}$.

211 Warren, Legislative and Judicial Attacks (pt. 1), supra note 107, at 20 (South Carolina); id. at 16-19 (Virginia); id. at 20-24 (Kentucky); Warren, Legislative and Judicial Attacks (pt. 2), supra note 29, at 166-73 (Georgia). 
section $25 .^{212}$ The other three members-James Buchanan of Pennsylvania, William W. Ellsworth of New York, and Edward D. White of Louisiana-signed the Counter Report. $^{213}$ No representative from New England, where support for judicial power in 1830 was the strongest, ${ }^{214}$ served on the House Judiciary Committee when repeal of section 25 was considered.

The overwhelming 138-51 congressional vote against the majority report demonstrated that opposition to federal judiciary authority was largely confined to South Carolina, Georgia, Virginia, and Kentucky. $^{215}$ Representatives from those four states provided almost two-thirds of the support for the committee recommendation, voting 33-12 for repeal. No other state with more than three representatives endorsed the majority report. ${ }^{216}$ The other large, slave state congressional delegations-North Carolina, Tennessee, and Maryland-voted 6-4, 4-3, and 8-0, respectively, against repeal. ${ }^{217}$ Representatives from northern states almost unanimously rejected the committee report. Only six free-state representatives favored repealing section 25 . Rejection was bipartisan. All sixty-seven National Republicans in Congress, including all sixteen National Republicans from slave states, voted against repeal. ${ }^{218}$ They were joined by sixty-nine of the 120 Jacksonians in Congress. Northern Jacksonians voted 51-6 against repeal.

American newspapers expressed no more enthusiasm for repeal than American legislators: The journalistic commentary on the repeal of section 25 was overwhelmingly negative. Seventeen newspapers, representing all sections of the United States, printed commentaries

212 The majority report was not signed. Report Upon the Judiciary, 7 REG. DEB. app. at Ixxvii (1831). I have simply reached the logical conclusion about the four representatives who did not sign the Counter Report. See infra note 213 and accompanying text.

213 Counter Report Upon the Judiciary, 7 REG. DEB. app. at lxxxvi (1831).

214 No New Englander supported the majority report by signing it. See Report Upon the Judiciary, 7 REG. DEB. app. at lxxvii (1831).

215 For the roll call vote in the House of Representatives, see 7 REG. DEB. 542 (1831) For the state and party of each representative, see Biographical Directory of the United States Congress 1774-Present, http://bioguide.congress.gov/biosearch/biosearch.asp (last visited Nov, 7, 2009) (fill fields using roll call information from 7 REG. DEB. 542 (1831)). The information in this paragraph is based on information from those two sources.

216 The one representative from Alabama and the one representative from Missouri voted for repeal. The Alabama delegation split 2-1 for repeal, but the Louisiana delegation split 2-1 against.

217 The lone representative from Delaware voted against repeal.

218 The two Anti-Masons also voted against repeal. 
opposing the majority report. $^{219}$ Only four newspapers supported repeal. $^{220}$

Anti-repeal articles effusively praised federal judicial power. The language of many commentators resolutely suggested a commitment to strong forms of judicial supremacy - the judicial power to authoritatively interpret constitutional provisions. "Repeal the vital part of the Judiciary Act," the Daily National Intelligencer proclaimed, "and we would not give a fig for the Constitution.",221 That journal made clear that maintaining federal judicial supremacy was vital because the Supreme Court was "the only effective barrier between liberty and tyranny under our Government."222 The New York Spectator described the proposed repeal as "fraught with the most imminent peril to the existence of this union."223

The congressional vote and public response to the House Judiciary Committee's proposed repeal of section 25 suggests that threats to federal judicial authority did not dramatically increase in the wake of the 1828 national election. Supreme Court decisions were not enforced in states where significant opposition existed. That, however, was as true before, as it was after, Jackson assumed the presidency. $^{224}$ The only immediate major consequence of the Jacksonian Revolution was that representatives opposed to federal judicial power became part, but only part, of the dominant national coalition for the first time since 1808 . One privilege of membership in this coalition proved to be the capacity to pack the House Judiciary Committee. Nevertheless, while Andrew Stephenson and his ideological allies could produce a committee report denouncing

219 These papers were the Indiana Journal, The Daily National Intelligencer (Wash., D.C.), The Augusta Chronicle (Ga.), the New Hampshire Statesman and State Journal, the New Hampshire Statesman and Concord Register, the New York Spectator, the Cherokee Phoenix and Indians' Advocate (Ga.), the Providence Patriot/Columbian Phenix (R.I.), the United States' Telegraph (Wash., D.C.), the Norwalk Gazette (Conn.), The Macon Daily Telegraph (Ga.), The New England Weekly Review (Conn.), the Boston Courier, the Virginia Free Press and Farmers' Repository (W. Va.), the Daily National Journal (Wash., D.C.), The Arkansas Gazette, and The Floridian.

220 These papers were the Louisville Public Advertiser, the Southern Times and State Gazette (S.C.), the Greenville Mountaineer (S.C.), and The Globe (Wash., D.C.). While most newspapers that were opposed to repeal printed multiple commentaries, only the Southern Times and State Gazette repeatedly supported repeal.

2212 CHARLES WARREN, THE SUPREME COURT IN UNITED STATES HistORY 196 (rev. ed. 1926).

222 DAILY NAT'L INTELLIGENCER (Wash., D.C.), Jan. 10, 1831.

223 The Judiciary, N.Y. SPECTATOR, Feb. 1, 1831.

224 See GOLDSTEIN, supra note 145, at 23-33. 
judicial review in 1831 , they could not even convince a majority of Jacksonian representatives to support their recommendations. The vote on repeal, as well as the public commentary, indicates that the constitutional politics of federal jurisdiction was not seriously altered during the initial transition to Jacksonian rule. Opponents of federal judicial power continued to be limited to representatives from states that had recently suffered judicial defeat or expected to suffer defeat in the very near future. ${ }^{225}$ The rest of the country, or at least the rest of the country interested in federal judicial power, continued regarding the federal judiciary as "the most sacred department of this [g]overnment.,"226

\section{B. Explaining Judicial Support in 1831}

James Buchanan did not bear an onerous burden of persuasion when defending the existing structure of judicial authority. Important differences between the majority and minority reports suggest that all members of the House Judiciary Committee were aware that strong, durable legislative majorities supported the judiciary's authority to declare federal and state laws unconstitutional in 1831. Most national representatives favored a strong federal judiciary, crucial passages in Buchanan's Counter Report suggested, because the federal judiciary could be counted on to defend such national policies as protective tariffs, the national bank, and federal land ownership in the small number of states where these popular measures were under constitutional attack. ${ }^{227}$ Davis's majority report, by comparison, did not link the repeal of section 25 to the maintenance of any popular national program. ${ }^{228}$ Southern anti-court activists appealed to northern Jacksonians on the basis of constitutional principles devoid of self-interest, rarely a winning political strategy.

Much of Davis's majority and Buchanan's minority reports was devoted to questions of constitutional interpretation and general principles of American constitutionalism. Both relied heavily on the stock arguments for and against federal judicial oversight that Americans had been developing since the Constitution was ratified. Davis emphasized the importance of state sovereignty. ${ }^{229}$ Buchanan

\footnotetext{
225 See supra note 211.

2262 REG. DEB. 912 (1826) (speech given by James C. Mitchell).

227 Counter Report Upon the Judiciary, 7 REG. DEB. app. at Ixxxiv (1831)

228 See Report Upon the Judiciary, 7 REG. DEB. app. at lxxx-1xxxi (1831)

229 Id. at Ixxviii.
} 
highlighted the importance of uniformity. ${ }^{230}$ Both cited the traditional authorities for their interpretation of federal judicial power. The majority report included long passages both from resolutions issued by Virginia and Kentucky and from several state court opinions declaring section 25 unconstitutional. ${ }^{231}$ The Counter Report cited the Supreme Court's opinions in Martin v. Hunter's Lessee and Cohens v. Virginia, while also citing the Federalist Papers. $^{232}$

Proponents and opponents of section 25 insisted that the constitutional text sanctioned their interpretation of federal judicial power. The Davis report asserted that the language of Article III limited the appellate jurisdiction of the Supreme Court to cases decided by the lower federal courts. ${ }^{233}$ "Did the convention contemplate, in using the term appellate jurisdiction, the right and power of taking an appeal from a State court to the Supreme Court?" Davis asked. $^{234}$ He concluded that:

The answer to these questions must be found in the [C]onstitution. ... In all other cases before mentioned, says the [C]onstitution, the Supreme Court shall have appellate jurisdiction. What courts have the original jurisdiction in all those cases before mentioned in the second section of the third article ..... Let the [C]onstitution answer: in "such inferior courts as Congress shall, from time to time, ordain and establish." Is a State court an inferior court? The [C]onstitution does not say so. If the framers of the [C]onstitution had so considered them, and had intended the right and power of taking an appeal from their judgments to the Supreme Court, it was an easy matter, and they, doubtless would have said so: their omitting to do so, is proof irresistible that the power was not intended to be given. It is unreasonable to believe that they who were so very precise and specific in the enumeration of cases and powers of infinitely less moment, would have left to implication and inference, a power that breaks down all the barriers between the State and Federal Governments.

Buchanan maintained that the text of Article III clearly contemplated that the Supreme Court would review state court decisions. $\mathrm{He}$ argued:

230 Counter Report Upon the Judiciary, 7 REG. DEB. app. at lxxxii (1831).

231 Report Upon the Judiciary, 7 REG. DEB. app. at lxxviii-1xxxi (1831).

232 Counter Report Upon the Judiciary, 7 REG. DEB. app. at lxxxiv-lxxxvi (1831).

233 Report Upon the Judiciary, 7 REG. DEB. app. at Ixxx (1831).

234 Id.

$235 I d$. (emphasis added). 
On the supposition contended for, it is wholly unaccountable that the framers of the [C]onstitution did not limit the natural effect of the words used in the first clause, by making the second to read "that, in all the other cases before mentioned," arising in the inferior courts of the United States, "the Supreme Court shall have appellate jurisdiction."

The majority and minority reports advanced conflicting notions of federal-state relationships under the Constitution. Champions of repeal insisted that section 25 subverted constitutional federalism. Davis complained that the constitutional justifications for federal appellate review empowered the Supreme Court "to prohibit State legislation by writs of injunction[,] to sequestrate State treasuries[,] . . . to imprison State functionaries, whether governors, judges, or State Legislatures, in a body," and, more generally, "to blot out from the map any State of the Union." ${ }^{237}$ Proponents of section 25 contended that national union depended on federal review of state court decisions. As Buchanan asserted:

[R]epeal would seriously endanger the existence of this Union. . . If this section were repealed, the General Government would be deprived of the power, by means of its own judiciary, to give effect either to the [C]onstitution which called it into existence, or to the laws and treaties made under its authority. It would be compelled to submit, in many important cases, to the decisions of State courts; and thus the very evil which the present [C]onstitution was intended to prevent would be entailed upon the people. The judiciary of the States might refuse to carry into effect the laws of the United States; and without that appeal to the Supreme Court which the 25th section authorizes, these laws would thus be entirely annulled, and could not be executed without a resort to force.

The repeal of section 25, Buchanan added, would create constitutional confusion; every state might interpret constitutional limitations differently. Buchanan declared, "Another reason for preserving this section is, that, without it, there would be no uniformity in the construction and administration of the [C]onstitution, laws, and treaties of the United States.

The dispute between the majority and minority reports was limited to vertical judicial review, the power of federal courts to declare state

236 Counter Report Upon the Judiciary, 7 REG. DEB. app. at Ixxxiv (1831).

237 Report Upon the Judiciary, 7 REG. DEB. app. at lxxx (1831).

238 Counter Report Upon the Judiciary, 7 REG. DEB. app. at lxxxiii-Ixxxiv (1831).

239 Id. at $1 \mathrm{xxxiii}$; see also id. at lxxxii ("All uniformity in their construction would thus be destroyed."). 
laws unconstitutional. The Southerners on the House Judiciary Committee did not question horizontal judicial review, the federal judicial power to declare federal legislation unconstitutional. The majority report took no position on the issues raised by the last paragraphs of Marbury v. Madison. Davis declared:

However, therefore, it may be admitted or denied, that the judicial department of the Federal Government is, in all questions submitted to it by the forms of the [C]onstitution, to decide in the last resort in relation to the authorities of the other departments of that Government, it can never be authorized so to decide in relation to the right of the parties to the constitutional compact, from which the judicial, as well as the other departments, hold their delegated trusts.

Most, but not all, Southerners accepted the granting of state judicial power to declare state laws unconstitutional. Judicial review was established in Virginia and South Carolina before Marbury was decided. ${ }^{241}$ Georgia courts had asserted the power to declare state laws unconstitutional without actually striking a state measure down. ${ }^{242}$ Kentucky was the only southern state represented on the House Judiciary Committee in which state judicial power was actively contested while Jackson was president. ${ }^{243}$

Proponents of repeal who accepted coordinate judicial review were far more concerned with limiting the authority of the federal government than the authority of federal courts. Section 25 was the objectionable means by which federal officials in all branches of the national government restricted state authority to determine constitutional meanings. Davis's majority report "denied that the judicial department of the Federal Government, or all the departments of that Government conjointly, were empowered to decide finally and authoritatively, in questions of sovereignty, controversies between a State and the Federal Government."244 Such a power was inconsistent with the southern compact theory. As Davis asserted, "[T]here was no common tribunal established by the [C]onstitution for such a purpose, and that consequently, each party had the right to judge of

\footnotetext{
240 Report Upon the Judiciary, 7 REG. DEB. app. at lxxix (1831).

241 See Cohen v. Hoff, 7 S.C.L. (2 Tread.) 657 (1814); Kamper v. Hawkins, 3 Va. (1 Va. Cas.) 20 (1793).

242 See Grimball v. Ross, 1 Ga. 175 (Super. Ct. 1808).

243 Theodore W. Ruger, "A Question Which Convulses a Nation": The Early Republic's Greatest Debate About the Judicial Review Power, 117 HARV. L. REV. 826, 844-55 (2004).

244 Report Upon the Judiciary, 7 REg. DEB. app. at Ixxviii (1831):
} 
and determine the extent of its own rights and powers."245 In his view, state sovereignty was violated whenever any national official challenged state constitutional decisions. "It is no more necessary to the harmonious action of the Federal and State Governments, that the federal courts should have power to control decisions of State courts by appeal," the majority report contended, "than that the Federal Legislature should have power to control the legislation of the States, or the Federal Executive a State Executive, by a negative." ${ }^{246}$ The problem with section 25 , from the perspective of anti-court Jacksonians, was that no agency of the federal government had the power to declare state laws unconstitutional.

The majority report made no effort to unite political interest with constitutional principle. The Davis report did not complain of any particular state policy that federal courts had declared unconstitutional or offer a realistic hypothetical instance of a federal judicial decision that might be ruinous to states. Representatives, Davis insisted, should be guided solely by constitutional concerns, while discounting mere matters of political gain. "The committee," the majority report stated, "believe [sic] that it is the imperative duty of Congress to repeal, without delay, any of its acts in contravention of the [C]onstitution, be the consequences what they may."247 Davis insisted at great length that arming federal courts with the power to declare local laws unconstitutional gave the "Supreme Court a supervisory and controlling power over twenty-four sovereign States."248 He did not explain why this "controlling power" was undesirable, particularly when federal courts were demanding that a few states respect policies that most national representatives thought to be in the national interest. The House Judiciary Committee made only a feeble effort to address Buchanan's claim that federal courts guaranteed legal uniformity. The majority merely cited Judge Spencer Roane's assertion in Hunter $v$. Martin that "it is no cause of offence [sic] to foreign nations, to have their causes decided, and exclusively and finally decided by the State tribunals."249 Neither Roane nor Davis discussed specific instances when foreign nations peacefully acquiesced in state court decisions that offered diverse

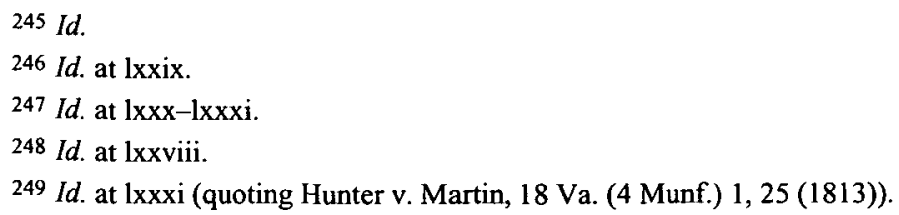


interpretations of federal treaties. Uniformity should not be considered a problem in practice, their arguments implied, because uniformity was not a problem in theory. ${ }^{250}$

The Counter Report made a greater effort to unite constitutional principle with practical advantage. Buchanan offered three thinly disguised hypothetical illustrations of how local majorities could thwart popular national policies if section 25 was repealed. The first considered tariff policy in the absence of federal judicial oversight. Buchanan asserted:

Suppose the Legislature of one of the States, believing the tariff laws to be unconstitutional, should determine that they ought not to be executed within its limits. They accordingly pass a law, imposing the severest penalties upon the collector and other custom-house officers of the United States within their territory, if they should collect the duties on the importation of foreign merchandise. The collector proceeds to discharge the duties of his office under the laws of the United States, and he is condemned and punished before a State court for violating this State law. Repeal this section, and the decision of the State court would be final and conclusive; and any State could thus nulljify any act of Congress which she deemed to be unconstitutional.

This example was followed by similar hypotheticals analyzing how repeal would influence national land and banking policies. Buchanan asked his fellow representatives to consider the consequences should either a governor declare "that the land belonging to the United States within her territory is now the property of the State, by virtue of her sovereign authority" ${ }^{\prime 252}$ or a state legislature declare the national bank "a nuisance, and inflict penalties upon all its officers for making discounts or receiving deposites [sic]." ${ }^{253}$ Although each example was phrased as a hypothetical, all had recently taken place. Several state legislatures had passed resolutions declaring protective tariffs unconstitutional. The South Carolina legislature had challenged the constitutionality of the tariff in $1828^{254}$ and would soon assert that federal revenue laws were "null, void, and no law, nor binding upon

\footnotetext{
250 See id. at lxxx-1xxxi.

251 Counter Report Upon the Judiciary, 7 REG. DEB. app. at lxxxiv (1831).

252 Id.

253 Id.

254 The South Carolina Protest Against the Tariff of 1828 (Dec. 19, 1828), reprinted in 1 DOCUMENTS OF AMERICAN HISTORY 249, 249-50 (Henry Steele Commager ed., 8th ed. 1968).
} 
this State, its officers or citizens." 255 Indiana and Mississippi had asserted that the federal government had no power to own lands within the state. ${ }^{256}$ Illinois was debating a similar resolution. In 1821, the Ohio legislature challenged the power of the Supreme Court to decide McCulloch v. Maryland. ${ }^{257}$ Other states were considering anti-bank resolutions. ${ }^{258}$ None of these resolutions had broad popular support when repeal was being debated. In 1831, Buchanan and strong congressional majorities favored protective tariffs, ${ }^{259}$ federal land ownership, ${ }^{260}$ and the national bank. ${ }^{261}$ Federal judicial authority, in these circumstances, was a vital means for enforcing these popular policies.

The tariff was a particular concern for Buchanan and his constituents.' When Buchanan served in the House of Representatives from 1821 to 1831 , he made numerous speeches championing protective tariffs and defending the constitutionality of that policy. In 1823, Buchanan declared protective tariffs "of great importance to the best interests of this country.",262 During the debate over the "Tariff of Abominations," he stated that the constitutionality of protective tariffs had "long since been settled." 263 He continued with the following:

255 South Carolina Ordinance of Nullification (1832) (repealed 1833), reprinted in 1 DOCUMENTS OF AMERICAN HISTORY, supra note 254, at 261, 261. Virginia and Georgia had passed resolutions that fell just short of nullification. North Carolina, Alabama, and Mississippi passed resolutions limited to declaring protective tariffs unconstitutional. See Extract from Report of North Carolina on the Tariff (Jan. 1828), in STATE DOCUMENTS, supra note 111, at 148, 148-50; Remonstrance of Alabama (Jan. 15, 1828), in STATE DOCUMENTS, supra note 111, at 150, 150-51; Resolutions of Mississippi (Feb. 5, 1829), in STATE DOCUMENTS, supra note 111 , at 156, 156.

256 Daniel Feller, THE PUblic LANDS IN JACKSONIAN POLITICS 118 (1984).

257 Extracts from the Report and Resolutions of Ohio Relative to the Bank and the Powers of the Federal Judiciary (Jan. 3, 1821), supra note 112, at 93-101.

258 RICHARD E. ELLIS, AGGRESSIVE NATIONALISM: MCCULLOCH V. MARYLAND AND THE FOUNDATION OF FEDERAL AUTHORITY IN THE YOUNG REPUBLIC 185-86 (2007).

259 See infra notes 262-70 and accompanying text.

260 See infra notes 271-77 and accompanying text.

261 See infra notes 278-82 and accompanying text.

262 James Buchanan, On the New Tariff Bill, Speech Before Congress (Feb. 7, 1823), in 40 ANNALS OF CONG. 893 (1823), reprinted in 1 THE WORKS OF JAMES BUCHANAN: Comprising His SpeEches, STATE PAPERS, AND PRIVATE CORRESPONDENCE, 18131830, at 56, 70 (John Bassett Moore ed., 1908) [hereinafter 1 THE WORKS OF JAMES BUCHANAN].

263 James Buchanan, Remarks Before Congress (Mar. 28, 1828), in 4 REG. DEB. 2039 (1828), reprinted in 1 THE WORKS OF JAMES BUCHANAN, supra note 262, at 320, 320. 
[T] he best interests of our country demand that every possible exertion should be made to procure the passage of an act of Congress imposing such duties as will enable our manufacturers to enter into fair competition with foreign manufacturers, and protect the farmer, the growers of hemp and wool, and the distiller of spirits from domestic materials, against foreign competition.

Representative Buchanan frequently declared himself a friend of the American system and "heartily approve[d]" of tariffs that protected major domestic concerns. ${ }^{265}$ His constituents in Pennsylvania were even more enthusiastic about protective tariffs. When Buchanan voted against the 1827 tariff as excessive, the resulting political storm convinced him to support even higher duties the next year. ${ }^{266}$.

Most national representatives from states, other than Virginia and the lower South, shared Buchanan's position on protective tariffs. Protection was even popular in early Jacksonian strongholds. When southern states attacked the constitutionality of the tariff in the mid1820 s, state legislatures in Ohio, New Jersey, Pennsylvania, Rhode Island, Indiana, and New York responded with resolutions affirming the constitutionality of that national policy. ${ }^{267}$ During Jackson's first term, Kentucky, Louisiana, Pennsylvania, New Jersey, Connecticut, and Vermont passed resolutions supporting protective tariffs. ${ }^{268}$ State legislators in Pennsylvania resolved that "the Constitution of the United States, authorises [sic] acts of Congress to protect manufactures, and that the actual prosperity of the country attests the wisdom of such acts. ${ }^{269}$ The Louisiana state legislature simply stated that "the Tariff [was] constitutional, expedient, and harmless to the southern states." ${ }^{270}$ In Ohio and Pennsylvania, public sentiment favoring the tariff may have played particularly crucial roles in the vote against repeal. In the early 1820 s, Ohio had vigorously opposed

\footnotetext{
264 James Buchanan, On the Tariff Bill, Speech Before Congress (Apr. 1-2, 1828), in 4 REG. DEB. 2089 (1828), reprinted in 1 THE WORKS OF JAMES BUCHANAN, supra note 262 , at 330,333 .

265 Id. at 335.

266 PhILIP SHRIVER Klein, President JAMEs BuChANAN: A BIOGRAPHy 64 (1962).

267 Counter Resolutions (1828), in STATE DOCUMENTS, supra note 111, at 151, 151-52.

268 Counter Resolutions (1830-1832), in STATE DOCUMENTS, supra note 111, at 158, 158.

269 Pennsylvania on the Powers of the Federal Government (Apr. 2, 1831), in STATE DOCUMENTS, supra note 111, at 162, 162-63.

270 Resolutions of Louisiana (Mar. 15, 1830), in STATE DOCUMENTS, supra note 111, at $161,162$.
} 
judicial power, and Pennsylvania had the highest percentage of Jacksonian representatives among northern states. Nevertheless, all thirty-five representatives from these two states supported section 25 in 1831.

In 1831, Buchanan believed the federal government was constitutionally authorized to incorporate a national bank and that incorporation was wise public policy. While a member of the Federalist Party in 1815, Buchanan condemned Republicans for "refusing the Bank of the United States a continuation of their charter."271 That Jeffersonian policy "embarrassed the financial concerns of the government, and withdr[ew] the only universal paper medium of the country from circulation. ${ }^{, 272}$ His enthusiasm for President Jackson in the 1820 s did not immediately diminish his enthusiasm for the national bank. In 1826, Buchanan spoke of "that firm and beautiful fabric, which the Supreme Court has already erected," 273 a fabric that included the judicial decision in $\mathrm{McCulloch}$ v. Maryland sustaining the constitutionality of the national bank. In 1832, Buchanan both rejected an invitation to become Secretary of the Treasury because "[h]e did not want to be the agent to destroy the Bank of the United States" and informed Jackson that he was "inclined to be friendly to the recharter of the Bank of the United States."274

Many Jacksonians, when repeal was being debated, had a similarly favorable assessment of the national bank. By the late 1820 s, Richard Ellis observes, the bank "had become well respected and even popular in some quarters." 275 One of those quarters was Jackson's first cabinet, a majority of which favored the renewing of the bank's corporate charter. ${ }^{276}$ During the early 1830 s, Congress was another bastion of support for the national bank. One year after rejecting the House Judiciary Committee report on repeal, majorities in both the House and Senate voted to extend the life of the national bank, and all of its privileges, for another twenty years. Although nominal Jacksonian majorities existed in both branches of the national

271 James Buchanan, Fourth of July Oration, Address Before the Washington Association of Lancaster (July 4, 1815), reprinted in 1 THE WORKS OF JAMES BUCHANAN, supra note 262 , at 2,4 .

$272 \mathrm{Id}$

2732 REG. DEB. 920 (1826).

274 KLEIN, supra note 266, at 97.

275 ELLIS, supra note 258, at 207.

276 See id. at 206, 210. 
government, nearly three-fifths of all representatives in both the House and Senate supported the national bank in $1832 .{ }^{277}$

Representatives from the states established in 1831 almost unanimously opposed claims that title to unowned lands automatically transferred from the federal government to the states when a territory entered the Union. Daniel Feller's study of public land policy in the early Jacksonian period details how "Northerners and Southerners, Adams and Jackson men, all spurned the Western claims."278 Buchanan's fellow representative from Pennsylvania, James Stephenson, spoke of the need to "effectually check . . . the giving away [of] this most invaluable national property." 279 Democrats from the slave states described cession as "unjust" and as evidence of "the grasping usurpations" of the newer states. ${ }^{280}$ Congress initially refused to publish state resolutions demanding cession, and then refused to debate the issue. ${ }^{281}$ A test proposal to cede some land in Tennessee was defeated by an overwhelming vote. ${ }^{282}$

James Buchanan, his fellow northern Jacksonians, and most members of the House of Representatives were not forced to choose between their constitutional principles and the interests of their constituents when voting on the proposed repeal of section 25. Most representatives believed that constitutional government in the United States depended on federal review of state court decisions. ${ }^{283}$ Thomas H. Crawford of Pennsylvania spoke for the national majority when he declared, "[T] he stroke that shall cut off the 25th section of the judiciary act from our code, will inflict a fatal wound upon the character of our common rights."284 Most legislators were also convinced that federal judicial review was likely to, more often than not, promote desired policies. In 1831, the Marshall Court was likely to support popular sentiment, at least in Congress, that protective tariffs, the national bank, and federal land policies were

277 For the House vote, see 8 REG. DEB. 3852 (1833). For the Senate vote, see 8 REG. DEB. 1073 (1833).

278 FELLER, supra note 256, at 109.

279 Id. (quoting Representative James Stephenson of Pennsylvania) (emphasis omitted).

280 Id. (quoting an unnamed Jacksonian from North Carolina).

281 Id. at 108.

282 Id. at 108-09.

283 See supra notes $238-39$ and accompanying text.

2847 REG. DEB. 658-59 (1831); see also 7 REG. DEB. 534 (1831) ("[T]he measure proposed by this bill [was] of as much importance as if it were a proposition to repeal the Union of these States."). 
constitutional. ${ }^{285}$ Outside of a few southern states, hardly any representative or political journalist worried about a Supreme Court decision that would declare either policies with strong national support or policies cherished in the more populous, free states unconstitutional. ${ }^{286}$ The dearth of debate and lack of primary sources make impossible firm statements about whether Buchanan's Counter Report merely preached to the choir, but the evidence suggests that persuading most representatives in 1831 that federal judicial review was desirable was not a Herculean accomplishment.

\section{The Waning of the Jacksonian Anti-Court Movement}

1831 was the highwater mark for Jacksonian attacks on federal courts. The following year, legislative proposals to either limit the scope of section 25 or abolish life tenure for federal Justices were easily defeated in the House of Representatives. ${ }^{287}$ Charles Warren's magisterial history of section 25 notes no serious effort to reduce federal jurisdiction or restrict the judicial power to declare laws unconstitutional during President Jackson's second term. ${ }^{288}$ Sporadic attacks on judicial power were renewed during the $1850 \mathrm{~s}$, but significant opposition to the crucial provisions in the Judiciary Act of 1789 had ceased for the political season. ${ }^{289}$

Proponents of federal judicial power during the early 1830s regained legislative momentum. Congress responded to the nullification crisis by passing legislation endorsed by President Jackson that augmented federal courts' authority. These courts, under the Force Act of 1833, became the first line of defense against local challenges to protective tariffs. That measure declared, "[T]he jurisdiction of the circuit courts of the United States shall extend to all cases ... arising under the revenue laws of the United States." ${ }^{290}$ Just before leaving office, Jackson signed the Judiciary Act of 1837. This bill added two Associate Justices to the Supreme Court, increased the number of lower federal court judges, and integrated all western states

285 See supra notes 262-81 and accompanying text.

286 See supra notes 215-23 and accompanying text.

287 See Warren, Legislative and Judicial Attacks (pt. 2), supra note 29, at 165, 175.

288 See id. at 175-76 (noting that the first major attack on judicial power after 1832 took place in 1854).

289 See id. at $176-85$.

290 Force Act of 1833, 4 Stat. 632, 632 (1833). 
that had been admitted to the Union in the past decades into the federal circuit court system. ${ }^{291}$

The tone of public debate reflected this renewed commitment to federal judicial authority. Gone, for the most part, were Jacksonian speeches condemning federal court oversight of state judicial decisions. Instead, a general consensus developed that federal courts with the power to declare state and federal laws unconstitutional were a blessing to American constitutionalism. Charles Hammond, a leader in the anti-Court fights during the $1820 \mathrm{~s}$, when referring to constitutional limitations during the 1830 s, stated, "It is only through the Supreme Court that this salutary restraint can be made impartially and effectually operative." 292 In 1835 , Buchanan, then a senator, asserted with great confidence, "It has then been established, that our present Judicial system shall not be abandoned.",293

Remarkably, Jacksonian attacks on judicial power waned as the coalition's attacks on the constitutional vision championed by the Marshall Court decisions intensified. Opposition to the national bank and protective tariffs became central planks of Jacksonian democracy during the 1830s. Abandoning the "big tent" in which Jacksonians initially captured the presidency, the Democratic Party platform in 1840 asserted, "[C]ongress has no power to charter a national bank," and "no more revenue ought to be raised, than is required to defray the necessary expenses of the government."294 For the next twenty years, every Jacksonian candidate for the presidency ran on a platform that repeated that litany. ${ }^{295}$ Jacksonians who articulated

\footnotetext{
291 See Nettels, supra note 161, at 225-26.

292 Warren, Legislative and Judicial Attacks (pt. 2), supra note 29, at 174.

293 CONG. Globe, 23 d Cong., 2d Sess. 280 (1835).

294 The American Presidency Project, Democratic Party Platforms: Democratic Party Platform of 1840 (May 6, 1840), http://www.presidency.ucsb.edu/ws/index.php?pid $=29572$.

295 See, e.g., The American Presidency Project, Democratic Party Platforms: Democratic Party Platform of 1844 (May 27, 1844), http://www.presidency.ucsb.edu/ws/ index.php?pid=29573; The American Presidency Project, Democratic Party Platforms: Democratic Party Platform of 1848 (May 22, 1848), http://www.presidency.ucsb.edu/ws/ index.php?pid=29574; The American Presidency Project, Democratic Party Platforms: Democratic Party Platform of 1852 (June 1, 1852), http://www.presidency.ucsb.edu/ws/ index.php?pid=29575; The American Presidency Project, Democratic Party Platforms: Democratic Party Platform of 1856 (June 2, 1856), http://www.presidency.ucsb.edu/ws/ index.php?pid=29576; The American Presidency Project, Democratic Party Platforms: Democratic Party Platform of 1860 (June 18, 1860), http://www.presidency.ucsb.edu/ws/ index.php?pid=29577.
} 
contrary sentiments in 1828 either converted or became Whigs. ${ }^{296}$ Only eastern Jacksonian opposition to cession remained constant during the turbulent $1830 \mathrm{~s}^{29}$.

James Buchanan moved in step with this Jacksonian tide. During Jackson's first term, he was a proponent of the Bank of the United States. ${ }^{298}$ By the end of Jackson's second term, Buchanan strongly opposed that institution. "It is mortifying to observe what a powerful influence the Bank of the U.S. exerts over the minds of those who consider themselves the well born \& the well bred of the land," he complained to Andrew Jackson. ${ }^{299}$ Repeating what had become orthodox Jacksonian dogma, Buchanan continued, "It is among the hard handed \& honest farmers \& mechanicks [sic] of the Count[r]y that the opposition to this Institution \& to a monied Aristocracy prevails." ${ }^{300}$ During the 1820 s, Buchanan was a leading proponent of protective tariffs. $^{301} \mathrm{He}$ abandoned this position during the $1840 \mathrm{~s}$. When James Polk became President, Buchanan claimed to support "a revenue Tariff with [only] moderate discriminations for incidental protection."302 In 1856, his campaign biography labored implausibly to demonstrate that the Pennsylvania Democrat had never supported a protective tariff per se as a young representative, but merely thought that protection could be a secondary purpose of a tariff whose primary purpose was revenue. ${ }^{303}$

Federal judicial power survived this regime transition both partly because the surviving Federalist/National Republican Justices were a bit more restrained during the Jackson presidency and partly because Joseph Story and Smith Thompson were the only Federalist/National Republican Justices who survived the Jackson presidency. The Supreme Court was noticeably less activist between 1828 and 1836 . Every significant opinion Justice John Marshall wrote that favored a

\footnotetext{
296 See DonAld B. COLE, The PRESIDENCY OF ANDREW JACKSON 211 (1993).

297 See FELLER, supra note 256, at 134-35.

298 See supra notes $271-75$ and accompanying text.

299 Letter from James Buchanan to General Andrew Jackson (July 28, 1837), in 3 THE WORKS OF JAMES BUCHANAN: COMPRISING HIS SPEECHES, STATE PAPERS, AND PRIVATE CORRESPONDENCE, 1836-1838, at 256, 256-57 (John Bassett Moore ed., 1908).

$300 \mathrm{Id}$. at 257.

301 See supra notes 262-66 and accompanying text.

302 Letter from James Buchanan to John W. Forney (July 29, 1846), in 7 THE WORKS of James Buchanan: Comprising HIS SPEeches, State PAPERS, and PRIVATE CORRESPONDENCE, 1836-1838, at 43, 43-44 (John Bassett Moore ed., 1909).

303 R.G. HORTON, THE LifE AND PUblic SeRvices of James BLCHANAN 65-66, 6869 (1856).
} 
state against either a claim of individual constitutional right or preemption by Congress was issued after John Quincy Adams was voted out of office. ${ }^{304}$ Barron $v$. City of Baltimore held that the first ten amendments to the Constitution did not limit state power. ${ }^{305}$ Providence Bank $v$. Billings held that courts would not imply immunity from taxation in state corporate charters. ${ }^{306}$ Willson $v$. Black Bird Creek Marsh Co. held that the Commerce Clause does not forbid states from damming navigable rivers when they do so to promote health. ${ }^{307}$ Breaking with earlier policy, Marshall declared in 1834 that the Justices would decide cases only when a majority of the entire Court supported the result and not merely a majority of the Justices voting. ${ }^{308}$ This novel practice, combined with judicial deaths and absences, prevented the Supreme Court from handing down decisions in several important cases concerning the constitutional limitations on state governments during the early 1830 s. $^{309}$ By the time that tribunal was fully staffed, the Marshall Court had become the Taney Court. Jackson had the opportunity to replace Marshall and four of the six sitting Associate Justices. ${ }^{310}$ The Judiciary Act of 1837 gave Martin Van Buren two additional Supreme Court appointments. $^{311}$ The reconstituted Supreme Court immediately

304 See JESSUP, supra note 144, at 284, 326, 405-06, 433-35; see also CHARLES F. HoBSON, THE GREAT CHIEF JUSTICE: JOHN MARSHALL AND THE RULE OF LAW 11 (1996) ("[W]hether by coincidence or for reasons of political expediency, the Supreme Court began to render decisions more favorable to state power.").

The one major state law that the Justices did declare unconstitutional after 1829 , the Missouri loan certificate program struck down in Missouri v. Craig, 29 U.S. (4 Pet.) 410 (1830), had already been both declared unconstitutional by Missouri courts and repealed by the state legislature.

Significantly, when the Marshall Court declared Georgia's attempt to assert jurisdiction over Cherokee soil unconstitutional, they issued an opinion that required a separate decision for enforcement - a decision that could only have been handed down after the 1832 national election. Had Jackson lost that election, the Marshall Court might have insisted on enforcement, but good legal grounds existed for not making that decision if Jackson won and the case not settled. See Graber, supra note 153, at 260-61.

30532 U.S. (7 Pet.) 243 (1833).

30629 U.S. (4 Pet.) 514 (1830).

30727 U.S. (2 Pet.) 245 (1829).

308 Briscoe v. Commonwealth Bank of Ky., 33 U.S. (8 Pet.) 118, 118 (1834); see also Warren, Legislative and Judicial Attacks (pt. 2), supra note 29, at 166.

309 See Warren, Legislative and Judicial Attacks (pt. 2), supra note 29, at 166.

310 ABRAHAM, supra note 38 , at 77-83; KATHLEEN M. SUllivan \& GERALD GUNTHER, CONSTITUTIONAL LAW app. at B-2 (16th ed. 2007).

311 ABRAHAM, supra note 38 , at $83-85$; Judiciary Act of 1837 , ch. $34, \S 1,5$ Stat. 176 (1837). 
sustained the state laws under constitutional attack in three important cases, New York v. Miln, ${ }^{312}$ Charles River Bridge v. Warren Bridge, ${ }^{313}$ and Briscoe v. Bank of Kentucky, ${ }^{314}$ that had been held over from the Marshall years. A dejected Joseph Story complained, "There will not, I fear, ever in our day, be any case in which a law of a State or of Congress will be declared unconstitutional; for the old constitutional doctrines are fast fading away." 315 Jacksonians were more enthusiastic. "The late renovation of the [C]onstitution of this august body, by the creation of seven of the nine members under the auspices of the present Democratic ascendancy," the Democratic Review of Washington triumphantly declared, "may be regarded as the closing of an old and the opening of a new era in its history.",316

The changing composition of the federal judiciary helps explain why James Buchanan remained a strong supporter of federal judicial power during the first decade of Jacksonian rule. As a member of the House of Representatives during the early $1830 \mathrm{~s}$, he led the fight to maintain section 25. As a member of the Senate during the late $1830 \mathrm{~s}$, Buchanan continued endorsing the expansion of federal judicial power and celebrating judicial supremacy, but with very different expectations about the course of that power. Representative Buchanan married support for the Bank of the United States to support for federal judicial authority. ${ }^{317}$ Senator Buchanan combined support for federal judicial authority with opposition to the national bank. He declared:

In my opinion a large majority of the people of [Pennsylvania], and myself among the number, believe that the creation of this vast moneyed monopoly, with the privilege of issuing bank paper to the amount of thirtyfive [sic] millions of dollars, is dangerous to our liberties, and to our dearest interests. We desire to try the question before the supreme judicial tribunal of the land, whether its charter is protected by the Constitution of the United States.

31236 U.S. (11 Pet.) 102 (1837).

31336 U.S. (11 Pet.) 420 (1837).

31436 U.S. (11 Pet.) 257 (1837).

315 Letter from Joseph Story to Justice John McLean, U.S. Supreme Court Justice (May 10, 1837), in 2 LIFE AND LETTERS OF JOSEPH STORY, supra note 109, at 272.

316 Nettels, supra note 161 , at 226.

317 See supra notes 251-53 and accompanying text.

318 CONG. GLOBE, 24th Cong., 2d Sess. 76 (1837). 
Judicial review, which had once functioned as a means for promoting state conformity with national policies, was now equally valued as a means for sweeping away the policies of a deposed regime.

Twenty years later, Buchanan reemphasized his commitment to judiciary supremacy when urging the Supreme Court to settle debates over the constitutional status of slavery. Whether slaveholders could bring their human chattel into the territories, his inaugural address declared, was "a judicial question, which legitimately belongs to the -Supreme Court of the United States, before whom it is now pending, and will, it is understood, be speedily and finally settled."319 This speech announced no new Jacksonian dogma. While some Jacksonians came to approve of the courts more slowly than others, the Democratic coalition as a whole had always supported judicial authority. Courts were sometimes useful means for imposing national policies on dissident localities, sometimes sites for removing the policy debris left by ousted administrations, and sometimes vehicles for diverting sectional issues from national, electoral politics. Despite both changing their views on many constitutional issues and the changing functions of federal courts, Buchanan and most northern Jacksonians had been committed to federal judicial power for more than thirty years, in part, because the tenor of federal court decisions evolved largely in lockstep with Jacksonian political circumstances and protean constitutional visions.

IV

FRAGMENTATION AND JUDICIAL POWER

Politics moves. Political fortunes, partisan alignments, the function of governing institutions, the most pressing issues of the day, and the frames for perceiving those issues are always changing. These constant developments cannot be fully captured by a legal history or a political science that provides only discrete descriptions of different institutions or snapshots of the entire political order at a particular time. Momentum matters whether the human activity be sports, medicine, or politics. Cancer treatments vary both with the size of the tumor and with whether the malignancy is growing or shrinking. Politics is as "constructed historically:" Karen Orren and Stephen Skowronek observe, "[T] he nature and prospects of any single part

319 President James Buchanan, Inaugural Address (Mar. 4, 1857), in 5 A COMPILATION OF THE MESSAGES AND PAPERS OF THE PRESIDENTS, 1789-1897, at 430, 431 (James D. Richardson ed., 1897). 
[of a political order is] best understood within the long course of political formation. ${ }^{, 320}$ Presidential capacity, at any point in time, depends on whether a particular partisan regime is consolidating or disintegrating. ${ }^{321}$ Poll results that reflect no change from the status quo have a different meaning than the same numbers when they reveal a long-term trend favoring one candidate. The choices reformers make are consequences of past decisions and political trends. "If we could first know where we are and whither we are tending," Abraham Lincoln pointed out, when explaining what could be done to limit the expansion of slavery, "we [might] better judge what to do and how to do it.",322

The snapshots on the previous pages highlight one way fragmentation promotes judicial power. Federal courts decide constitutional issues without fear of political retaliation as long as one institution, or institutional player with the power to block attacks on the judiciary, prefers that existing judges be vested with the responsibility for making particular decisions rather than the probable alternative. The more institutions or institutional players with veto power, the greater the likely size of the jurisprudential space in which Justices may freely roam. In 1827, President John Quincy Adams could be counted on to protect judicial authority. In 1831, James Buchanan and a House majority rejected an effort to abolish the judicial power to declare state laws unconstitutional. Had the House voted to repeal section 25 in 1833, that measure would have gone down in defeat in the Whig-controlled Senate. The faces on the annual photograph taken of politicians favoring judicial review would change from 1789 to 1837 , but the picture would always include a working majority of at least one elected branch of the national government.

These stills cry out to be integrated into a motion picture providing a developmental account of judicial power in the United States. Numerous snapshots depict judicial power feeding on fragmentation, but the particular institutions and political factions providing the needed judicial nutrition change-sometimes fairly rapidly. The President, House, and Senate, from 1827 until 1833, took turns being

\footnotetext{
320 ORREN \& SKOWRONEK, supra note 48, at 1.

321 See generally STEPHEN SKOWRONEK, THE POLITICS PRESIDENTS MAKE: LEADERSHIP FROM JOHN ADAMS TO BILL CLINTON (1997).

322 Abraham Lincoln, "A House Divided," Speech at the Illinois Republican State Convention (June 16, 1858), in 2 COLLECTED WORKS OF ABRAHAM LINCOLN 461, 461 (Roy P. Basler ed., 1953) (emphasis in original).
} 
the main bulwarks against attacks on the federal court system. This alternation suggests the possibility that American politics develops in ways that render all three elected branches of the national government lining up against the judiciary as a highly unlikely scenario. If this is so, then the main theory of political change underlying many studies on the political foundations of judicial authority needs revising.

Students of American constitutional development work within variations of classical realignment theory when explaining historical support for judicial review in the United States. ${ }^{323}$ Politics, in this view, is an ongoing cycle of coming together and falling apart. One or two critical elections bring a united, partisan coalition to power that shapes politics for the next thirty years or so. During the years immediately following these critical elections, that coalition controls the national government and is fairly united on common goals. Over time, politics fragments. Coalition members begin to fight amongst themselves over particular policies and sometimes lose control of the Presidency, House, or Senate. Soon after, another series of critical elections takes place that brings a new dominant political coalition to power.

Judicial power, prominent works suggest, is determined by this political cycle. $^{324}$ The size of the jurisprudential space in which Justices are free to roam increases as politics disintegrates, then sharply decreases in the wake of the political consolidations that mark critical elections. Reconstruction Presidents who attain office during critical elections attack a federal judiciary still controlled by members of the electorally deposed coalition. Once the reconstructive President has made the appointments necessary for a more friendly court system, the party in power expands federal judicial power as insurance against their eventual weakening. When the weakening does occur, the still-dominant party looks to the courts to maintain policies that no longer command adequate support in the elected branches of the national government.

American constitutional politics from 1820 until 1840 is consistent with many, but not all, aspects of this realignment synthesis. The Marshall Court thrived in the early 1820 s as the National Republican

323 Two prominent studies of classical realignment theory are Bumham, Critical Realignment, supra note 21, at 101-39, and JAMES L. SUNDQUIST, DYNAMICS OF THE PARTY SYSTEM: ALIGNMENT AND REALIGNMENT OF POLITICAL PARTIES IN THE UNITED STATES $1-49$ (rev. ed. 1983). The rest of this paragraph summarizes these works.

324 See WHITTINGTON, supra note 16, at 28-229; Graber, supra note 36, at 37-45. The rest of this paragraph summarizes Whittington's important book. 
order was disintegrating. Jackson's election in 1828 inaugurated a period of increased attacks on judicial review. The consolidation of the Jacksonian regime during the late $1830 \mathrm{~s}$ led to legislation expanding the federal judiciary. Realignment theory does not, however, explain the enthusiasm northern Jacksonians displayed for federal courts in 1831. Buchanan did not act consistently with contemporary understandings of the constitutional politics after critical elections. Contrary to Burnham's expectations, Buchanan did not attack the federal court system. ${ }^{325}$ Contrary to Lasser's hypothesis, Buchanan did not urge fellow partisans in the House to preserve judicial power for future use. ${ }^{326}$ Contrary to Whittington's contentions, Buchanan did not regard judicial supremacy as an unfortunate, but entrenched, feature of the constitutional order. ${ }^{327}$ Instead, three years after the critical election of 1828 had taken place, Buchanan and the Jacksonian majority in Congress still seemed supportive of the National Republican constitutional vision being championed by the Marshall Court.

David Mayhew's criticisms of realignment theory ${ }^{328}$ and the concept of "intercurrence" ${ }^{329}$ provide a better theoretical framework for understanding Buchanan's support for the federal judiciary and the similar support shown by his fellow Jacksonians in the House of Representatives. Mayhew acknowledges that the shape of the political universe changes, but its development takes place slowly and incrementally. "Big bangs," in his view, are not the only forces that shape the American political universe. "[E]lectoral politics," Mayhew contends, "is to an important degree just one thing after another." ${ }^{330}$ Orren and Skowronek use the expression "intercurrence" to describe the erratic patterns that characterize political transitions in the United States. ${ }^{331}$ They insist that "the normal condition of the polity [is] that of multiple, incongruous authorities operating simultaneously." 332 No single thread unites all governing arrangements in the United States. Rather, they observe, "the institutions of a polity . . . are created . . . at different times, in the

\footnotetext{
325 Burnham, Critical Realignment, supra note 21, at 124.

326 See LASSER, supra note 41, at 258-59.

327 See WhitTINGTON, supra note 16, at 284.

328 See generally MAYHEW, supra note 44.

329 ORREN \& SKOWRONEK, supra note 48, at 108.

330 MAYHEW, supra note 44, at 147.

331 ORREN \& SKOWRONEK, supra note 48, at 108.

332 Id.
} 
light of different experiences, and often for quite contrary purposes." 333

Combined, these observations suggest a regime in which powerful forces, such as an economic depression, a foreign policy crisis, or a dramatic change in the mass electorate, influence rather than overwhelm the distinctive developmental logics of relatively autonomous governing institutions. How the separated branches of the national government respond to events that restructure the political order depends, in part, on external events and, in part, on the internal dynamics of those institutions. Presidents are historically more sensitive to foreign affairs than the national legislature. ${ }^{334}$ World War II fostered greater attention to racial equality, in part, because Americans were fighting a racist state ${ }^{335}$ and, in part, because the New Deal had increased the number of racial liberals in prominent government positions. ${ }^{336}$

Early nineteenth-century constitutional politics provides one example of the complex interaction between outside phenomena and the distinctive features of each branch of the national government. All governing institutions were influenced by the rise of mass political parties and near-universal white male suffrage. The relative democratization of American politics had an immediate and powerful effect on presidential elections, which depended on whether a coalition could turn out more voters in crucial states. Democratization had a later, and far more subdued, influence on the Senate, which was staffed by persons appointed by the state legislature.

Fragmentation or intercurrence provides space for judicial power at particular times and serves as the primary vehicle for preserving that space over time. Somewhat separated political institutions are likely to have somewhat different perspectives on the course of judicial decisions. These differences create opportunities for relatively autonomous judicial policymaking. During the 1960s, apportionment took place without successful partisan challenge because the Democratic Presidents who anticipated a more liberal Congress were far more sympathetic to the judicial decision in Baker v. $\mathrm{Carr}^{337}$ than

333 Id. at 112.

334 See Aaron Wildavsky, The Two Presidencies, 4 TrANS-ACTION 7, 7 (1966).

335 See Philip A. KLINKNER \& Rogers M. SMiTH, THE UnSTEADY MARCH: THE Rise AND DECLINE OF RACIAL EQUALITY IN AMERICA 136-201 (1999).

336 See MCMAHON, supra note 59, at 97-176.

337369 U.S. 186 (1962). 
House members whose hold on office was rendered more precarious. ${ }^{338}$ Fragmented political institutions are also characterized by partly distinctive developmental trajectories. The Presidency, Senate, and House react to the same external stimulus in different ways partly because of their internal logics. Not only are these institutions likely to occupy somewhat different spaces in the political universe, they are always likely to be moving at somewhat different speeds in somewhat different directions. Roe v. Wade ${ }^{339}$ remained good law during the 1990s because, while the House of Representatives and Senate became more conservative, the presidency was occupied by a Democrat who appointed two pro-choice Justices, Ruth Bader Ginsburg and Stephen Breyer, to the Supreme Court.

While periods of political transition change the location of the jurisprudential spaces in which federal courts may freely operate, the relative autonomy of each elected branch of the national government tends to maintain the size of that space over time. Any event that pushes all elected branches of the national governing coalition in one general direction is likely to push federal courts in the same direction at, perhaps, a slightly slower speed than one branch and a somewhat faster speed than another. The federal legislature, federal executive, and federal courts were all more committed to racial equality in 1965 than in 1945, although different events played crucial roles in the evolution of each branch. By the time all relevant elected institutions can be aligned against the old Court, the same forces that produced this new electoral majority are likely to bring forth a new Court, whose positions are within the new jurisprudential space generated by the new partisan configuration.

Separated institutions moving at slightly different speeds in somewhat different directions help explain why the elected branches of national government did not unite in common opposition to Marshall Court politics until the Marshall era ended. During the early years of the Jackson presidency, most southern Jacksonians challenged federal judicial power, but almost all northern Jacksonians supported the Marshall Court. Native American concerns aside, President Jackson remained on the sidelines. The result was a stalemate, with a slight movement away from Marshall orthodoxy once Henry Baldwin was appointed to replace Bushrod

338 See LuCaS A. Powe, JR., The Supreme Court AND the Amerucan Elite, 17892008 , at 263 (2009).

339410 U.S. 113 (1973). 
Washington. ${ }^{340}$ Jackson could be said to have become truly committed to what is now considered the Jacksonian constitutional revolution only in 1832, with the veto of the National Bank Bill. ${ }^{341}$ During his second term of office, he was joined by many free state Democrats who adjured their former support for the national bank and protective tariffs. ${ }^{342}$ William Johnson's death in 1834 further weakened National Republican influence on the Supreme Court, but Whig control of the Senate prevented Jackson from nominating Roger Taney to that judicial vacancy. ${ }^{343}$ After Jacksonians triumphed in midterm Senate elections, they soon found themselves with an additional two judicial openings-Marshall and Gabriel Duvall-to fill. ${ }^{344}$ At the moment when, for the first time, all three branches of the national government were controlled by Jacksonians committed to abandoning the central constitutional themes of the Marshall Court, Joseph Story was the only Justice left standing who articulated that jurisprudential vision.

Separated institutions moving at slightly different speeds in somewhat different directions also help explain failures to curb judicial power during the most momentous political transitions of the twentieth century. The New Deal empowered liberals in the executive branch of the national government but did not change the character of Southern Democrats in Congress. The Confederacy rose again when Franklin Roosevelt proposed packing the Court in $1937 .^{345}$ As Kevin McMahon details, "The Court-packing plan was the last straw for many congressional southerners who were already unnerved by the elimination of the two-thirds rule, the [P]resident's increasingly progressive positions, and the addition of black American voters to the Roosevelt coalition., ${ }^{346}$ Fearing the appointment of racial liberals, conservatives in the Senate preferred preserving the judicial status quo to increasing presidential influence on judicial decision making. ${ }^{347}$ After World War II, fragmentation sustained judicial power after the country moved rightward. Lyndon Johnson exercised considerable power as Senate Majority Leader by

\footnotetext{
340 See ABRAHAM, supra note 38, at 73-74.

341 See COLE, supra note 296, at 96-106.

342 See id. at 211.

343 See ABRAHAM, supra note 38 , at 74-75.

344 Id.

345 MCMAHON, supra note 59 , at 80-81.

346 Id. at 81 .

347 See id. at $80-81$.
} 
inhibiting conservative attacks on a more liberal Supreme Court during the $1950 \mathrm{~s} .{ }^{348}$

The same political phenomenon has sustained judicial power for the past forty years. After 1968, Great Society policies were stalled or abandoned in dribs and drabs, with governing institutions becoming more conservative at significantly different speeds and at different times. Such liberal judicial opinions as Roe v. Wade were, nevertheless, immune from conservative attack because Democrats controlled the House of Representatives until 1994, the Presidency from 1992 until 2000, and the Senate from 2000 until 2002. When Republicans finally gained control of all three elected branches of the national government in 2002, the federal judiciary had become as much a political ally as an oppositional force. Two Reagan judicial appointees, Sandra Day O'Connor and Anthony Kennedy, were the swing Justices. A conservative icon, William Rehnquist, was Chief Justice. During the previous decade, the tribunal he led had proved as willing to engage in conservative activism as liberal activism. ${ }^{349}$

The perfect storm may hit as a consequence of the 2008 national elections. Fairly liberal Democratic Party majorities now control all three elected branches of the national government. The median Justice, Anthony Kennedy, is a conservative Republican. A fair possibility exists that President Obama and the Democratic Congress will pass legislation regulating matters that the judicial majority insists are constitutionally reserved to the states. Should the Roberts Court aggressively seek to constrain this emerging dominant national coalition, Obama and his allies may be compelled to contemplate the political actions necessary to weaken judicial authority over official constitutional meanings.

The "multiple, incongruous authorities" 350 that constitute the American regime nevertheless counsel against predicting a repeat of 1936. While the predominant winds for the past forty years have blown in a rightward direction, prominent countercurrents have influenced all elected branches of the national government in ways that shape the present federal judiciary. The Clinton interregnum

\footnotetext{
348 See POWE, supra note 338 , at 238.

349 See Thomas M. KeCK, The Most Activist Supreme COURT IN History: The ROAD TO MODERN JUDICIAL CONSERVATIVISM 199-253 (2004).

350 ORREN \& SKOWRONEK, supra note 48 , at 108.
} 
generated two moderately liberal Justices. ${ }^{351}$ Justice John Stevens is the residue of liberal Republican influence on the judicial selection process during the $1970 \mathrm{~s} .{ }^{352}$ Democratic majorities in the Senate from 1986 until 1994 both prevented the confirmation of Robert Bork $^{353}$ for the seat Justice Kennedy presently holds and almost certainly inhibited the first Bush administration from nominating a more reliable conservative than David Souter. ${ }^{354}$ To the extent President Obama insists on a radical departure from inherited practices, he is likely to encounter opposition from moderate Democrats who will regard the Roberts Court as an ally in their effort to prevent politics from moving too far to the left. In short, the dynamics of the political universe in 2009 are as likely as in the past to ensure that federal courts will move within, rather than without, the jurisprudential space created by the ongoing motion of fragmented institutions.

351 See ABRAHAM, supra note 38, at 317-26; DAVID Alistair Yalof, PurSUit OF Justices: PResidential Politics and the SElection of SuPREME COURT NomineES 196-205 (1999).

352 See ABRAHAM, supra note 38, at 276-79; YALOF, supra note 351, at 125-31.

353 See ABRAHAM, supra note 38, at 297-99.

354 YALOF, supra note 351, at 191-92. 
